University of Nebraska - Lincoln

DigitalCommons@University of Nebraska - Lincoln

\title{
Annual baseflow variations as influenced by climate variability and agricultural land use change in the Missouri River Basin
}

\author{
Laurent Ahiablame \\ Aleksey Y. Sheshukov \\ Kansas State University, ashesh@ksu.edu \\ Vahid Rahmani \\ University of Kansas, vrahmani@ksu.edu \\ Daniel Moriasi \\ USDA-ARS, daniel.moriasi@ars.usda.gov
}

South Dakota State University, laurent.ahiablame@sdstate.edu

Follow this and additional works at: https://digitalcommons.unl.edu/usdaarsfacpub

Ahiablame, Laurent; Sheshukov, Aleksey Y.; Rahmani, Vahid; and Moriasi, Daniel, "Annual baseflow variations as influenced by climate variability and agricultural land use change in the Missouri River Basin" (2017). Publications from USDA-ARS / UNL Faculty. 1832.

https://digitalcommons.unl.edu/usdaarsfacpub/1832

This Article is brought to you for free and open access by the U.S. Department of Agriculture: Agricultural Research Service, Lincoln, Nebraska at DigitalCommons@University of Nebraska - Lincoln. It has been accepted for inclusion in Publications from USDA-ARS / UNL Faculty by an authorized administrator of DigitalCommons@University of Nebraska - Lincoln. 
Research papers

\title{
Annual baseflow variations as influenced by climate variability and agricultural land use change in the Missouri River Basin
}

\author{
Laurent Ahiablame ${ }^{\mathrm{a}, *}$, Aleksey Y. Sheshukov ${ }^{\mathrm{b}}$, Vahid Rahmani ${ }^{\mathrm{b}, \mathrm{c}}$, Daniel Moriasi ${ }^{\mathrm{d}}$ \\ ${ }^{a}$ Department of Agricultural and Biosystems Engineering, South Dakota State University, Brookings, SD 57007, USA \\ ${ }^{\mathrm{b}}$ Department of Biological and Agricultural Engineering, Kansas State University, Manhattan, KS 66506, USA \\ ${ }^{\mathrm{c}}$ Kansas Biological Survey, University of Kansas, Lawrence, KS 66047, USA \\ ${ }^{\mathrm{d}}$ USDA-ARS Grazinglands Research Laboratory, El Reno, OK 73036, USA
}

\section{A R T I C L E I N F O}

\section{Article history:}

Received 26 May 2016

Received in revised form 25 May 2017

Accepted 26 May 2017

Available online 31 May 2017

\section{Keywords:}

Watershed hydrology

Groundwater discharge

Cultivated cropland

Precipitation

Elasticity coefficient

\begin{abstract}
A B S T R A C T
The Missouri River system has a large water storage capacity, where baseflow plays an important role. Understanding historical baseflow characteristics with respect to climate and land use impacts is essential for effective planning and management of water resources in the Missouri River Basin (MORB). This study evaluated statistical trends in baseflow and precipitation for 99 MORB minimally disturbed watersheds during 1950-2014. Elasticity of baseflow to climate variability and agricultural land use change were quantified for the 99 studied watersheds. Baseflow was derived from daily streamflow records with a recursive digital filter method. The results showed that baseflow varied between 38 and $80 \%$ ( 0 and $331 \mathrm{~mm} /$ year) of total streamflow with an average of $60 \%$, indicating that more than half of streamflow in the MORB is derived from baseflow. The trend analysis revealed that precipitation increased during the study period in 78 out of 99 watersheds, leading to 1-3.9\% noticeable increase in baseflow for 68 of 99 watersheds. Although the changes in baseflow obtained in this study were a result of the combined effects of climate and land use change across the basin, upward trends in baseflow generally coincide with increased precipitation and agricultural land use trends in the basin. Agricultural land use increase mostly led to a $0-5.7 \%$ decrease in annual baseflow in the basin, except toward east of the basin where baseflow mostly increased with agricultural land use increase (0.1-2.0\%). In general, a $1 \%$ increase in precipitation and a $1 \%$ increase in agricultural land use resulted in $1.5 \%$ increase and $0.2 \%$ decrease in baseflow, respectively, during the study period. These results are entirely dependent on the quality of data used; however, they provide useful insight into the relative influence of climate and land use change on baseflow conditions in the Great Plains region of the USA.
\end{abstract}

(c) 2017 Elsevier B.V. All rights reserved.

\section{Introduction}

Baseflow is an important component of streamflow (Santhi et al., 2008; Ahiablame et al., 2013; Rumsey et al., 2015). As such, understanding its availability and contribution to streamflow are critical for appropriate planning and management of water resources (Santhi et al., 2008). Baseflow discharge to streams has been associated with a wide range of drivers including climate, topographical relief, geology, soils, vegetation, and human activities (Zhang and Schilling, 2006; Price, 2011).

\footnotetext{
* Corresponding author.

E-mail addresses: laurent.ahiablame@sdstate.edu (L. Ahiablame), ashesh@ksu. edu (A.Y. Sheshukov), vrahmani@ksu.edu (V. Rahmani), daniel.moriasi@ars.usda.
} gov (D. Moriasi).
With growing concerns regarding potential adverse impacts of global climate change and land use change on water resources (IPCC, 2014a,b; Xu et al., 2013a), analysis of baseflow trends is salient within the context of changes in hydroclimatology of a region (Zhang and Schilling, 2006). Global climate observations indicate more frequent extreme events since the early 20th century typified by increases in temperature, precipitation, and atmospheric greenhouse gas concentrations with direct impacts on regional water resources (NOAA, 2016) Continued global warming has led to intensification of hydrologic regimes (e.g. Nyenje and Batelaan, 2009; Price, 2011), with regional differences and patterns (Price, 2011). Baseflow feedback to the global warming has been extreme, especially seasonal baseflow which increased with earlier snowmelt, leading to reduced late-summer baseflow (e.g. Yusoff et al., 2002; Brabets and Walvoord, 2009; Huntington et al., 2009; Xie et al., 2010). Recently, Ficklin et al. (2016) also showed that climate 
driven changes in baseflow in United States watersheds vary across the nation and seasons; except in the northeast where climate change contributed to consistent baseflow increase during fall and winter and decrease during all seasons in the southwest. In the Midwest and Great Plains regions, analysis of historical streamflow records revealed increasing trends in streamflow and baseflow due to the influence of climate (e.g. Lins and Slack, 2005; Novotny and Heinz, 2006; Kibria et al., 2016).

While baseflow response to climate change has been a topic of interest (e.g. Choi, 2008; Smakhtin, 2001; Price, 2011), baseflow trends have concurrently been associated with land use change (e.g. Price, 2011; Juckem et al., 2008; Ma et al., 2009). Very often, climate impact amplifies the effect of land use and vice versa (Poff, 1996; Price, 2011; Choi, 2008), especially in regions where both climate and land use intensity are pronounced. For example, Juckem et al. (2008) linked changes in baseflow timing to climate and changes in baseflow magnitude to land use change in the Kickapoo River watershed, Wisconsin. In Tanzania, varying patterns of streamflow and baseflow trends, reported over a 50-year (19602009) study period in the Usangu watershed, were attributed to climate and anthropogenic influences which include deforestation, irrigation, and groundwater abstraction (Shu and Villholth, 2012). Based on the climate and land use change analysis in east of MORB, covering four states in the Midwest (Ohio, Indiana, Illinois, and Iowa), Xu et al. (2013a) reported that baseflow increase in 58\% of the studied watersheds was predominantly caused by land surface changes. Although it is a challenge to clearly differentiate the respective influence of climate and land use change on streamflow processes in many settings, years of research showed that land use change and human-induced influences are equally notable contributors to changes in baseflow. In Iowa watersheds, increased baseflow in nearly all 11 watersheds studied was linked to improved land management and conservation practices, greater artificial drainage, increasing row crop production, and channel incision (Schilling and Libra, 2003). Zhang and Schilling (2006) showed that increasing baseflow in the Mississippi River Basin is the result of land use change and associated agricultural activities, leading to increased streamflow in this basin. In contrast, Wen and Chen (2006) reported decreases in baseflow for 20 out of 24 streams across Nebraska mainly because of changes in land use and groundwater withdrawal for irrigation. Similarly, Brikowski (2008) documented decreased baseflow for western Kansas following land use change and irrigation demands. Zomlot et al. (2015) observed a large spatial variation in recharge and baseflow in northern part of Belgium, largely driven by vegetation cover and groundwater depth.

The MORB is a major basin with considerable sources of water for agriculture, municipal, rural, and industrial use in the United States (Kammerer, 1987; Norton et al., 2014; Mehta et al., 2016). Like other parts of the world, the MORB region is experiencing risks of climate change and impacts of land use change (Mehta et al., 2013, 2016; Xu et al., 2013a; Norton et al., 2014), that affect its hydrological processes. For example, statistical significant trends in annual streamflow, likely due to the influence of climate and land use, were reported for 101 out of 227 streamflow gauges in the MORB between 1960 and 2011 (Norton et al., 2014). As an important component of streamflow, climate and land use exert substantial influence on baseflow processes (Price, 2011). Research showed that baseflow represents more than $50 \%$ of total streamflow in the United States Midwest and Great Plains regions (e.g. Santhi et al., 2008; Ahiablame et al., 2013; Rumsey et al., 2015). To continue to meet critical water demands, as mentioned above, there is a need to provide relevant science-based information to increase understanding of the role of regional controls on MORB baseflow. Knowledge of past trends as well as factors that directly influence baseflow processes in the MORB adds to the existing information system to support development of resilient adaptation and mitigation strategies for climate and land use changes. The goal of this study was to document the influence of climate and land use changes on baseflow in the MORB over the past few decades. The specific objectives were to (1) document regional patterns of baseflow trends in the MORB; and (2) quantify the relative influence of climate variability and land use change on baseflow by utilizing established statistical methods.

\section{Study area}

The MORB is a $1,350,000 \mathrm{~km}^{2}(521,238$ square miles $)$ watershed that covers, wholly or partly, Montana, North Dakota, South Dakota, Minnesota, Wyoming, Nebraska, Iowa, Colorado, Kansas, and Missouri in the United States (approximately 1,320,000 $\mathrm{km}^{2}$ ), and south of Alberta and Saskatchewan in Canada (approximately $30,000 \mathrm{~km}^{2}$ ) (Fig. 1). The watershed has many landscape feature classes, ecoregions, and climates from the Northern, Middle, and Southern Rocky Mountains to the west, the Missouri Plateau to the north, and the High Plains to the east and south (Fenneman and Johnson, 1946; Norton et al., 2014). The MORB drains about one-sixth of the North American continent into the Missouri River (MOR). With 4,087.7 km (2540 miles), the MOR is the longest river in the United States (Kammerer, 1987; Norton et al., 2014). The states within the MORB rely heavily on the watershed for economic and ecological stability through support for agriculture, livestock, recreation, tourism, wildlife habitat, irrigation, drinking water, industry, and electrical power generation (Burch et al., 2007; Wyoming State Wildlife Action Plan, 2010).

The predominant land uses within the MORB consists of pasture/grassland (47\%) and crop production agriculture (25\%), while the rest of the land consists of shrub (10\%), forest (9\%), residential/urban (3\%), wetlands ( $2 \%$ ), and others (4\%; water, snow, barren, and no data) (Fig. 1; Homer et al., 2015). Corn, soybean, and wheat are the predominant crops.

The climate of the MORB can be classified as cold deserts and western Cordillera in the mountainous west, semiarid prairies in the central part of the watershed, and temperate prairies to the east (USEPA, 2006; Norton et al., 2014). During the coldest month of the year (i.e. January) and warmest month of the year (i.e. July), average daily air temperature in the MORB varies from $-8{ }^{\circ} \mathrm{C}$ to $37{ }^{\circ} \mathrm{C}$, and $-16^{\circ} \mathrm{C}$ to $30^{\circ} \mathrm{C}$, respectively in Billings (MT) and Bismarck (ND) in the north, and from $-9{ }^{\circ} \mathrm{C}$ to $32^{\circ} \mathrm{C}$, and $-6{ }^{\circ} \mathrm{C}$ to $32{ }^{\circ} \mathrm{C}$, respectively in Omaha (NE) and Kansas City (MO) in the south. Average annual rainfall varies from west to east with the least amount of precipitation in the west $(<255 \mathrm{~mm})$ and the greatest amount of precipitation in the east $(>1140 \mathrm{~mm}$ ) (Norton et al., 2014; Table 1). Total annual snow depth varies widely across the watershed with $1400 \mathrm{~mm}$ in Billings, MT, $1300 \mathrm{~mm}$ in Bismarck, ND, $670 \mathrm{~mm}$ in Omaha, NE, and $340 \mathrm{~mm}$ in Kansas City, MO.

\section{Data and methods}

\subsection{Data}

Ninety-nine streamflow gauge stations within the MORB were collected from the U.S. Geological Survey National Water Information System database (USGS-NWIS, 2015) based on the following criteria (Fig. 1): (1) the streamflow gauge stations must contain continuous data for at least 50 years (monthly or daily data), (2) have reduced or be completely free from water diversion, reservoir storage, and other anthropogenic regulations, and (3) have irrigated land occupying less than $10 \%$ of the draining watersheds. Of the 99 stations that satisfied these criteria, 53 stations were part of the USGS's Hydro-Climatic Data Network (HCDN; Slack and Landwehr, 1992), 


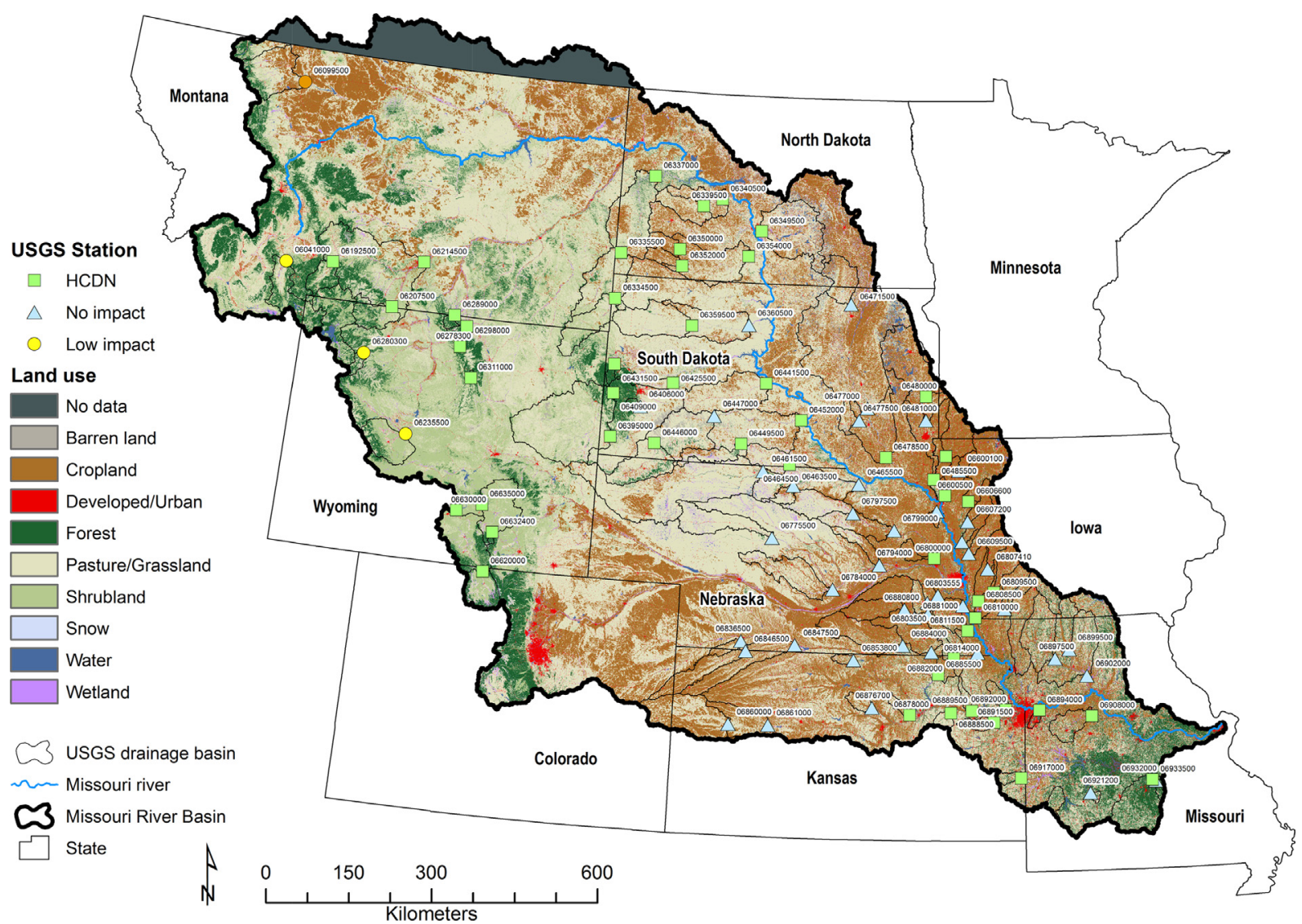

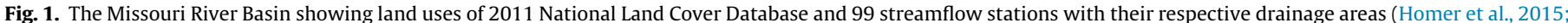
USGS-NWIS, 2015; HCDN: Hydro-Climatic Data Network).

Table 1

Watershed characteristics per state in the Missouri River Basin.

\begin{tabular}{|c|c|c|c|c|c|c|c|}
\hline State & $\begin{array}{l}\text { Area } \\
\left(\times 1000 \mathrm{~km}^{2}\right)\end{array}$ & $\begin{array}{l}\text { Precip } \\
\text { (mm/year) }\end{array}$ & $\begin{array}{l}\text { Temp } \\
\left({ }^{\circ} \mathrm{C}\right)\end{array}$ & $\begin{array}{l}\text { Elevation } \\
(\mathrm{m})\end{array}$ & $\begin{array}{l}\text { Slope } \\
(\%)\end{array}$ & $\begin{array}{l}\text { Agricultural land use } \\
(\%)\end{array}$ & $\begin{array}{l}\text { Non-agricultural land use } \\
(\%)\end{array}$ \\
\hline Colorado & 76.9 & 428 & 7.5 & 1778 & 6.3 & 15 & 85 \\
\hline Iowa & 45.0 & 795 & 9.0 & 381 & 3.2 & 52 & 48 \\
\hline Kansas & 104.4 & 710 & 11.8 & 571 & 2.6 & 33 & 67 \\
\hline Minnesota & 4.7 & 672 & 6.7 & 493 & 1.6 & 78 & 22 \\
\hline Missouri & 94.5 & 1002 & 12.1 & 272 & 3.8 & 20 & 80 \\
\hline Montana & 314.9 & 382 & 5.4 & 1207 & 8.3 & 8 & 92 \\
\hline Nebraska & 200.3 & 576 & 9.2 & 647 & 3.0 & 34 & 66 \\
\hline North Dakota & 105.8 & 421 & 5.1 & 795 & 2.9 & 29 & 71 \\
\hline South Dakota & 193.8 & 482 & 7.4 & 675 & 3.0 & 31 & 69 \\
\hline Wyoming & 181.8 & 366 & 5.4 & 1835 & 9.1 & 2 & 98 \\
\hline
\end{tabular}

43 stations were found to have very minimal to no impact from diversion, regulation or irrigation, and three stations had less than $10 \%$ of draining land impacted by irrigation. Areas of the draining watersheds ranged from $61.5 \mathrm{~km}^{2}$ in the farthest upstream tributaries in Wyoming to $54,708 \mathrm{~km}^{2}$ of the James River in South Dakota. 66 stations situated upstream of the other stations, resulting in 66 nested watersheds. No streamflow stations were selected at the main stem of Missouri River. A complete list of the selected USGS streamflow gauge stations is provided in the attached Supplementary material A (see also MORB_99_Cats; MORB_99_Sites).

Precipitation data were extracted from the Applied Climate Information System, which was developed and is maintained by the National Oceanic and Atmospheric Administration Regional Climate Centers located in Lincoln, NE, USA (NOAA-RCC, 2015). Weather stations with less than $10 \%$ of missing data for their longest available data were determined mainly within a $50-\mathrm{km}$ radius distance from the 99 streamflow gauge stations and selected for the analysis. For 12 of the streamflow gauge stations, weather stations were found to be outside of the $50-\mathrm{km}$ radius due to good weather data availability (see Supplementary material B). A complete list of the weather stations used in this study and details of each station as well as their related streamflow gauge stations is attached in Supplementary material B.

For ease of analyses in this study, land use was categorized as cropland ("cultivated"), comprising all crop types, and noncropland (Table 1). Cultivated cropland, referred to in this study as agricultural land use, was evaluated because the MORB is often depicted as an important "breadbasket" which supports substantial production of food and feed crops on nonirrigated land (Mehta et al., 2016). Annual cropland areas planted for each county of the states within the MORB were selected and downloaded from the USDA National Agricultural Survey Statistics Quick Stats 
(USDA-NASS, 2015) for the period 1950-2014. County areaweighted averaging approach was utilized to calculate cropland areas for 99 watersheds associated with the selected USGS stations (not shown here). Cropland area was subtracted from total basin area to determine non-cropland area.

Total crop production area for each state was validated by comparing the NASS cropland area with the NRCS 2010 National Resources Inventory summary report (USDA, 2013) and were found to be similar. Although, the data quality is sufficient for analyses at the study basin scale, it is important to note that there may be some uncertainty associated with the land use data because several states within the MORB included only a portion of their counties (Fig. 1). The uncertainty is due to the fact that the Crop Data Layers (CDLs) have many single pixels or small pixel clusters, which are classified as crop fields due to spectral artifacts, and impractically large polygons classified as fields due to CDL's limited ability to distinguish between field boundaries (Zhang et al., 2015a). For example, the 2009-2012 CDLs underestimated total rice acreage by $2-12 \%$ for Colorado County and overestimated total cotton acreage by $1-10 \%$ for Dawson County in Texas, which Zhang et al. (2015a) attributed to the inability of the CDLs to distinguish rice or cotton fields from road networks.

\subsection{Baseflow separation}

The Web-based Hydrograph Analysis Tool (WHAT; Lim et al., 2005) was used to estimate baseflow from long-term streamflow records (1950-2014). WHAT has three methods for baseflow separation: local minimum (Sloto and Crouse, 1996), a one-parameter digital filter or BFLOW filter (Lyne and Hollick, 1979), and twoparameter filter or Eckhardt filter (Eckhardt, 2005). The Eckhardt filter method (Eckhardt, 2005, 2008) was used on daily streamflow for baseflow separation in this study. The Eckhardt filter has been validated and widely used in similar analyses (Eckhardt, 2008; Lim et al., 2005; Ahiablame et al., 2013). It is mathematically expressed as (Eckhardt, 2005, 2008):

$Q_{b f_{k}}=\frac{\left(1-B F I_{\max }\right) \cdot \alpha \cdot Q_{b f_{k-1}}+(1-\alpha) \cdot B F I_{\max } \cdot Q_{s f_{k}}}{1-\alpha \cdot B F I_{\max }}$

where $\mathrm{Q}_{\mathrm{bf}}$ is the filtered baseflow; $\mathrm{Q}_{\mathrm{sf}}$ is the total streamflow; $\alpha$ is the recession constant; $\mathrm{BFI}_{\max }$ is the maximum baseflow index (BFI) that can be modeled by the algorithm; and $\mathrm{k}$ is the time step number. Under the condition that $\mathrm{Q}_{\mathrm{bf}} \leq \mathrm{Q}_{\mathrm{sf}}$, baseflow for the first time step was assumed $50 \%$ of streamflow by the algorithm. Baseflow index is the proportion of baseflow in long-term streamflow records, expressed as a percentage (e.g., Eckhardt, 2005, 2008; Santhi et al., 2008; Ahiablame et al., 2013).

The two parameters of Eckhardt filter consist of recession constant and BFImax (Eckhardt, 2005). The former is derived by recession analysis and describes the rate at which streamflow decreases with time following a recharge event (e.g. rainfall). The latter refers to the maximum baseflow index (BFI) that can be modeled by the recursive digital filter algorithm. $\mathrm{BFI}_{\max }$ exerts substantial influence on the estimated baseflow, but it is a non-measurable parameter unless calibrated with known hydrological and/or hydrogeological characteristics of the watershed under study (Eckhardt, 2005). While a formal accuracy assessment of the Eckhardt filter algorithm was not conducted for each subwatersheds of MORB, the algorithm proves to be robust for baseflow separation in various climatic and physiographic conditions (Eckhardt, 2005, 2008).

\subsection{Trend analysis}

The modified Mann-Kendall (MK) test was used to evaluate temporal trends in baseflow and precipitation (cultivated crop- land) in the MORB for the period of 1951-2014. The test is modified from the original MK test (Kendall, 1975; Mann, 1945). Generally applied to detect a significant monotonic increase or decrease trend in long-term time series data, the MK test has been widely used in hydroclimatic trend studies (e.g. Zhang et al., 2015b; Dudley and Hodgkins, 2013; Rahmani et al., 2015). The test statistic, S, is calculated as (Hirsch et al., 1982; Lins and Slack, 1999; Dixon et al., 2006):

$S=\sum_{i=1}^{n-1} \sum_{j=i+1}^{n} \operatorname{sgn}\left(X_{j}-X_{i}\right)$

where $\mathrm{n}$ is the sample size, and

$\operatorname{sgn}\left(x_{j}-x_{i}\right)=\left\{\begin{array}{c}+1 \text { if }\left(X_{j}-X_{i}\right)>0 \\ 0 \text { if }\left(X_{j}-X_{i}\right)=0 \\ -1 \text { if },\left(X_{j}-X_{i}\right)<0\end{array}\right.$

where $X_{i}$ and $X_{j}$ are the sequential values in the dataset. The Matlab R2015a (The MathWorks, Inc., Natick, MA) was used for the analysis at a $10 \%$ significance level. A positive value of $S$ indicates an increasing trend and a negative $S$ indicates a decreasing trend. With the mean, $E(S)=0$, the variance of $S$ is calculated as (Zhang et al., 2015b; Kumar et al., 2009):

$V(S)=\frac{n(n-1)(2 n+S)}{18}$

where $\mathrm{n}$ is the sample size (i.e. $\mathrm{X}_{1}, \mathrm{X}_{2}, \mathrm{X}_{3}, \ldots \mathrm{X}_{\mathrm{n}}$ ). The normal Z-test statistic is given by (Hirsch et al., 1982; Kumar et al., 2009):

$Z=\left\{\begin{array}{l}\frac{S-1}{\sqrt{V(S)}} \text { for } S>0 \\ 0 \text { fo } S=0 \\ \frac{S+1}{\sqrt{V(S)}} \text { for } S<0\end{array}\right.$

The null hypothesis of "no trend in the time series" is rejected at a significance level of $\alpha$ if $\left|Z_{j}\right|>Z_{(1-\alpha / 2)}$, where $Z_{(1-\alpha / 2)}$ is the value of the standard normal distribution with a probability of exceedance of $\alpha / 2$.

The modified MK test has been shown robust against serial autocorrelation and to detect the significance of trends without affecting the power of the test compared to the classical MK test (Hamed and Rao, 1998; Yue et al., 2002; Kumar et al., 2009). The modified MK test differs from the classical MK test in the computation of the variance, which is expressed as (Kumar et al., 2009):

$V^{\prime}(S)=V(S) \frac{n}{n^{\prime}}$

$\frac{n}{n^{\prime}}=1+\frac{2}{n(n-1)(n-2)} \sum_{i=1}^{n-1}(n-i)(n-i-1)(n-i-2) r_{i}$

where $V^{\prime}(S)$ is the modified $V(S) ; r_{i}$ is the lag-i significant autocorrelation coefficient of rank i of time series, given by (Salas et al., 1980; Yue et al. 2002; Kumar et al., 2009):

$r_{k}=\frac{\frac{1}{n-k} \sum_{i=1}^{n-k}\left(X_{i}-\bar{X}\right)\left(X_{i+k}-\bar{X}\right)}{\frac{1}{n} \sum_{i=1}^{n}\left(X_{i}-\bar{X}\right)^{2}}$

where $r_{k}$ is the lag-k autocorrelation function that describes the correlation between two values of the same variable at times $i$ and $i$ $+\mathrm{k}$; and $\bar{X}$ is the mean of the sample data. Trend analysis was not conducted on agricultural land use data because as mentioned in Section 3.1, there are some irregularities in the data; and assessment of these irregularities is beyond the intended scope of this study.

The trend magnitude in baseflow and precipitation over time were calculated using Sen slope estimator (Sen, 1968), which is 
an estimate of the trend slope for X (in Eq. (6)) over time, calculated as the median of linear slopes between all possible combinations of pairs for the entire dataset within the study period (Hirsch et al., 1982):

$\beta=\operatorname{median}\left(\frac{X_{j}-X_{i}}{j-i}\right)$

where $\mathrm{X}$ is annual baseflow or precipitation; $\mathrm{i}$ and $\mathrm{j}$ are consecutive years with $\mathrm{i}$ always less than $\mathrm{j}$; and $\beta$ is the Sen's slope estimator which indicates the change in $\mathrm{X}$ (i.e. baseflow and precipitation) per year.

\subsection{Sensitivity of mean annual baseflow to climate variability and agricultural land use change}

The concept of elasticity (Schaake, 1990) was used to evaluate sensitivity of baseflow to changes in climate. The concept has also been used to evaluate sensitivity of runoff to land use changes (Yao et al., 2009; Zheng et al., 2013; Zhao et al., 2014). The nonparametric estimator proposed by Sankarasubramaniam et al. (2001) was used in this study to estimate climate and agricultural land use elasticity of annual baseflow. The elasticity estimator can be expressed as (Sankarasubramaniam et al., 2001):

$e_{P}=\operatorname{median}\left(\frac{Q_{b f(t)}-\bar{Q}_{b f}}{P_{t}-\bar{P}} \frac{\bar{P}}{\bar{Q}_{b f}}\right)$

$e_{A g L U}=\operatorname{median}\left(\frac{Q_{b f(t)}-\bar{Q}_{b f}}{A g L U_{t}-\overline{A g L U}} \frac{\overline{A g L U}}{\bar{Q}_{b f}}\right)$

where $e_{\mathrm{P}}$ and $\mathrm{e}_{\mathrm{AgLU}}$ are, respectively, climate and agricultural land use elasticity coefficients of annual baseflow; $\bar{P}, \overline{\mathrm{AgLU}}$, and $\bar{Q}_{\mathrm{bf}}$ are the mean annual precipitation, agricultural land use, and baseflow, respectively; $P_{t}$ and $\mathrm{Q}_{\mathrm{bf}(\mathrm{t})}$ are pairs of data points (for climate elasticity of baseflow) as well as $\mathrm{AgLU}_{\mathrm{t}}$ and $\mathrm{Qbf}_{\mathrm{bt}}$ (for agricultural land use elasticity of baseflow) in the annual time series. While this non-parametric estimator has been proven to be a robust technique for estimating elasticity coefficients (Sankarasubramaniam et al., 2001; Chiew et al., 2006; Fu et al., 2011; Zhao et al., 2014), the approach uses annual data and portrays elasticities of long-term baseflow to changes in long-term precipitation and agricultural land use conditions.

For ease of the result description the streamflow gauge number related to each weather station and land use watershed will be used when referring to all three parameters (baseflow, precipitation, and agricultural land use).

\section{Results and discussion}

\subsection{Mean, variability, and spatial distribution of baseflow}

The spatial mean of the average annual estimated (filtered) baseflow for the 99 watersheds was $74 \mathrm{~mm}$ for the 1950-2014 study period, with a minimum of $0 \mathrm{~mm} /$ year for the Niobrara River near Verdel (Station 06465500) in Nebraska to a maximum of $331 \mathrm{~mm} /$ year for the South Fork Shoshone River near Valley
(06280300) in Wyoming (Table 2). These baseflow estimates are within the range of 0 to $700 \mathrm{~mm}$ reported by Santhi et al. (2008) for that region. Without looking at the hydrological regime of the catchments, baseflow tends to vary more in small catchments compared to large catchment areas, based on Fig. 2.

Baseflow varies notably from east to west across the MORB (Fig. 3; Norton et al., 2014). For the 65 years of records, average baseflow appears to be higher in the west mountain region of Wyoming and Montana, and far-east of the watershed in Iowa and Missouri. Baseflow was lower towards the middle of the watershed in North Dakota, South Dakota, Nebraska, and Kansas, which are located in the heart of the Great Plains. Baseflow in the western mountain region varies between 68 and $331 \mathrm{~mm} / \mathrm{year}$, while baseflow is largely within the range of 80 and $200 \mathrm{~mm} / \mathrm{year}$ downstream of the basin (i.e. east) (Fig. 3). Baseflow yield in the Plains ranges from 0 to $50 \mathrm{~mm} /$ year (Fig. 3).

Low baseflow yield in the Plains is likely due to the combination of land use and low elevation settings. This part of the basin is predominantly grassland and cropland (Fig. 1), which foster permanent canopy decrease and less deep-rooted plants. Much of the Great Plains are covered by Mollisols (especially the humid region), which are dark, soft, grassland soils; they are fertile soils but somewhat poorly to very poorly drained (Hall and Crovetti, 2007). Previous research showed that land cover types with shallow-rooted plants such as grasses usually have less infiltration capacity than deeply rooted forests or woodlands (Bruijnzeel, 2004; Wilcox et al., 2008a; Wine and Zou, 2012). The western mountain has the highest baseflow yield compared to other parts of the basin. This may be explained by the presence of forest supported by high elevations of the Rocky Mountains (Fig. 3; Norton et al., 2014), high precipitation, and low temperature (Rumsey et al., 2015). In the Southern Great Plains, researchers reported increasing trends in baseflow with tree cover increased (Wine and Zou, 2012). Wilcox et al. (2008b) also showed that increased baseflow, in central Texas watersheds, was attributable to deeply rooted trees and greater infiltration capacity of soils as degraded grasslands were converted to woodlands. A strip of forest, grassland, and shrubland is also observable in the Ozark Plateaus in Missouri, downstream of the basin, leading to relatively elevated baseflow yield (Fig. 3; Norton et al., 2014). Upstream of the Ozark Plateaus, baseflow yield is moderate in the Central Lowland (100 to $200 \mathrm{~mm} / \mathrm{year}$ ) (Fig. 3; Norton et al., 2014). The east of the basin lies on moderately lower elevations in a blend of forest, grassland, shrubland, and cropland compared to the heavily forested Rocky Mountains side (Fig. 3; Norton et al., 2014). These findings are consistent with a study by Rumsey et al. (2015), which reported that baseflow typically increased with elevation in the Upper Colorado River Basin. High terrain settings have greater influence on baseflow processes, as topographic gradients govern soil water movement downslope, regulating the amount of water reaching the channel network or retained in the soil profile (Price, 2011; Devito et al., 2005; Tetzlaff et al., 2009). While it seems logical that deeply rooted trees would decrease streamflow due to high evapotranspiration and shallow-rooted trees would increase baseflow, this theory might not hold true if the deep-rooted trees do not transpire directly from aquifers or perched water tables (Wine and Zou, 2012; Price, 2011). Depending on topography, soil, water abstraction and import, land

Table 2

Summary of catchment area, baseflow yield, coefficient of variation in baseflow yield, and baseflow index of the Missouri River Basin 99 catchments used in the study.

\begin{tabular}{|c|c|c|c|c|}
\hline & Catchment area (sq.km) & Baseflow yield (mm/year) & $\mathrm{CV}$ & BFI \\
\hline Mean & 6461 & 74 & 0.79 & 0.60 \\
\hline Median & 3182 & 55 & 0.67 & 0.59 \\
\hline Minimum & 61 & 0 & 0.09 & 0.38 \\
\hline Maximum & 54,707 & 331 & 2.59 & 0.80 \\
\hline
\end{tabular}



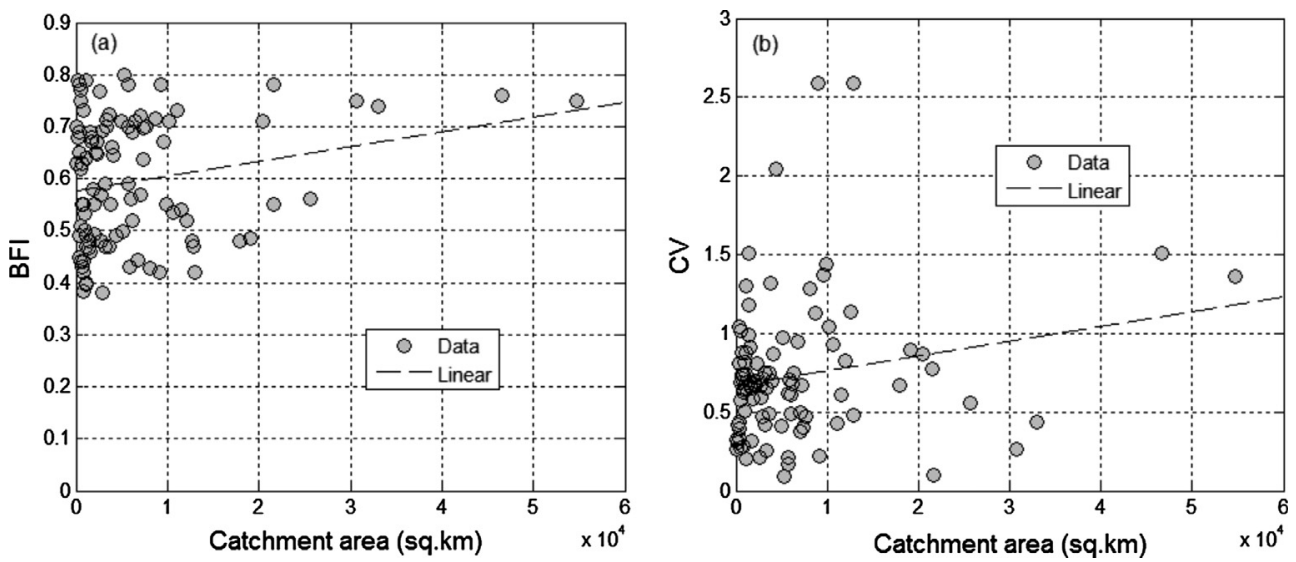

Fig. 2. BFI versus catchment area (a); CV's versus catchment area (b) in the Missouri River Basin.

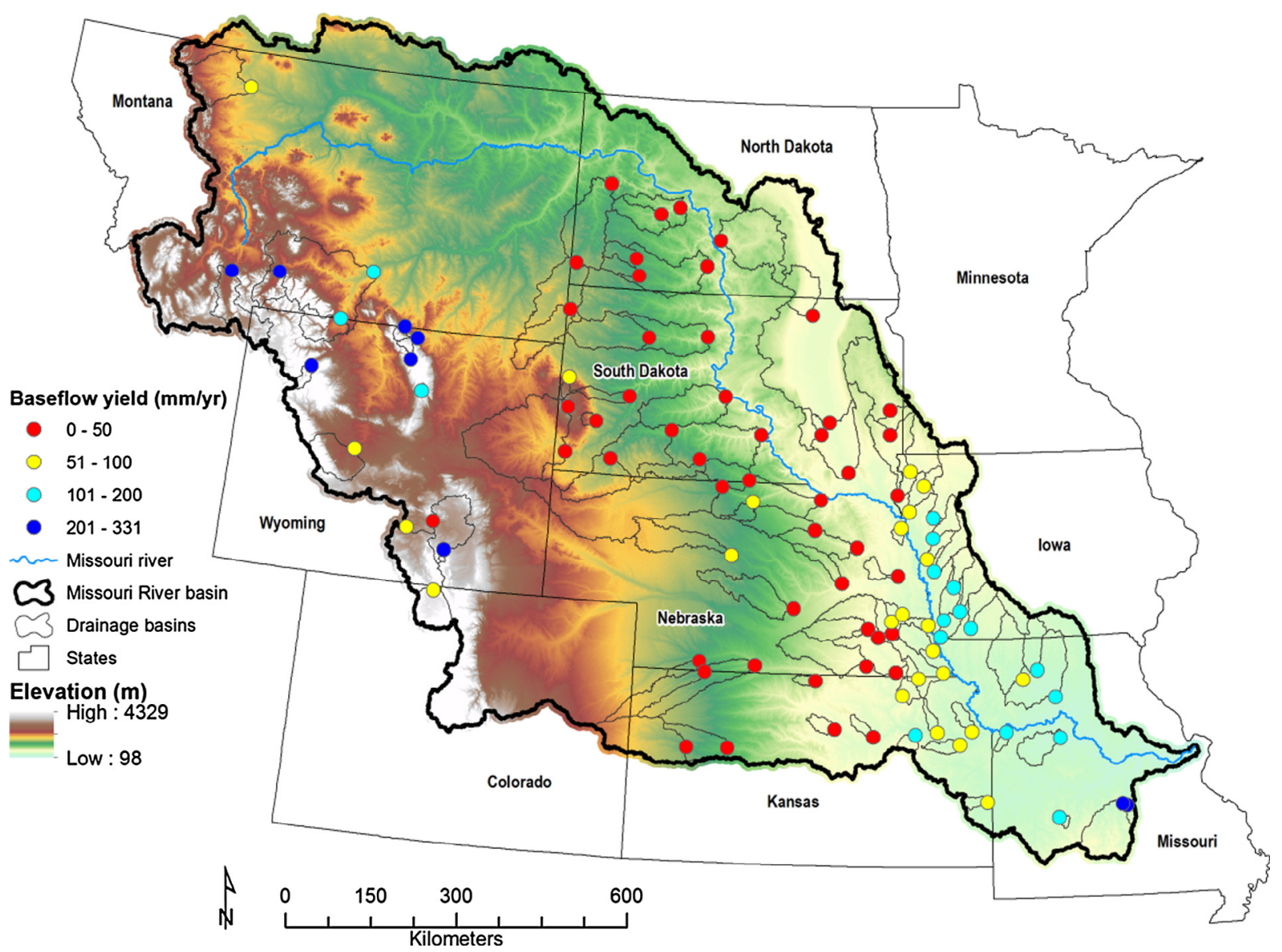

Fig. 3. Average annual baseflow yield in the Missouri River Basin.

use, and levels of alternation induced in the watershed, baseflow may increase or decrease, indicating the complexity of the influence of watershed characteristics on baseflow (Price, 2011).

Proportions of baseflow in total streamflow in the 99 streams, as indicated by BFI values, range from 0.38 to 0.80 , with an average of 0.60 , indicating that baseflow constitutes approximately $60 \%$ of total streamflow in the MORB (Table 2; Fig. 2). Previous studies in the Midwest and northern Great Plains states also reported similar BFI values (Santhi et al., 2008; Ahiablame et al., 2013; Schilling and Helmers, 2008). As baseflow is an important component of streamflow, understanding the spatial-temporal variation of baseflow is of great value to development of water resources (Santhi et al., 2008). BFI values are higher in the far west (i.e. upstream) and a pocket in the center of the basin (Fig. 4). Compared to baseflow yield, BFI values reveal that about half of the stream in central MORB draw heavily from the contribution of groundwater storage, while streamflow is runoff-dominated towards the basin outlet during the study period (Figs. 3 and 4). As mentioned earlier, western MORB is a mountain area with high terrain, forest, and high precipitation, which support high contribution of baseflow to streamflow (Norton et al., 2014; Rumsey et al., 2015). This is not quite the case downstream of the basin where the presence of 


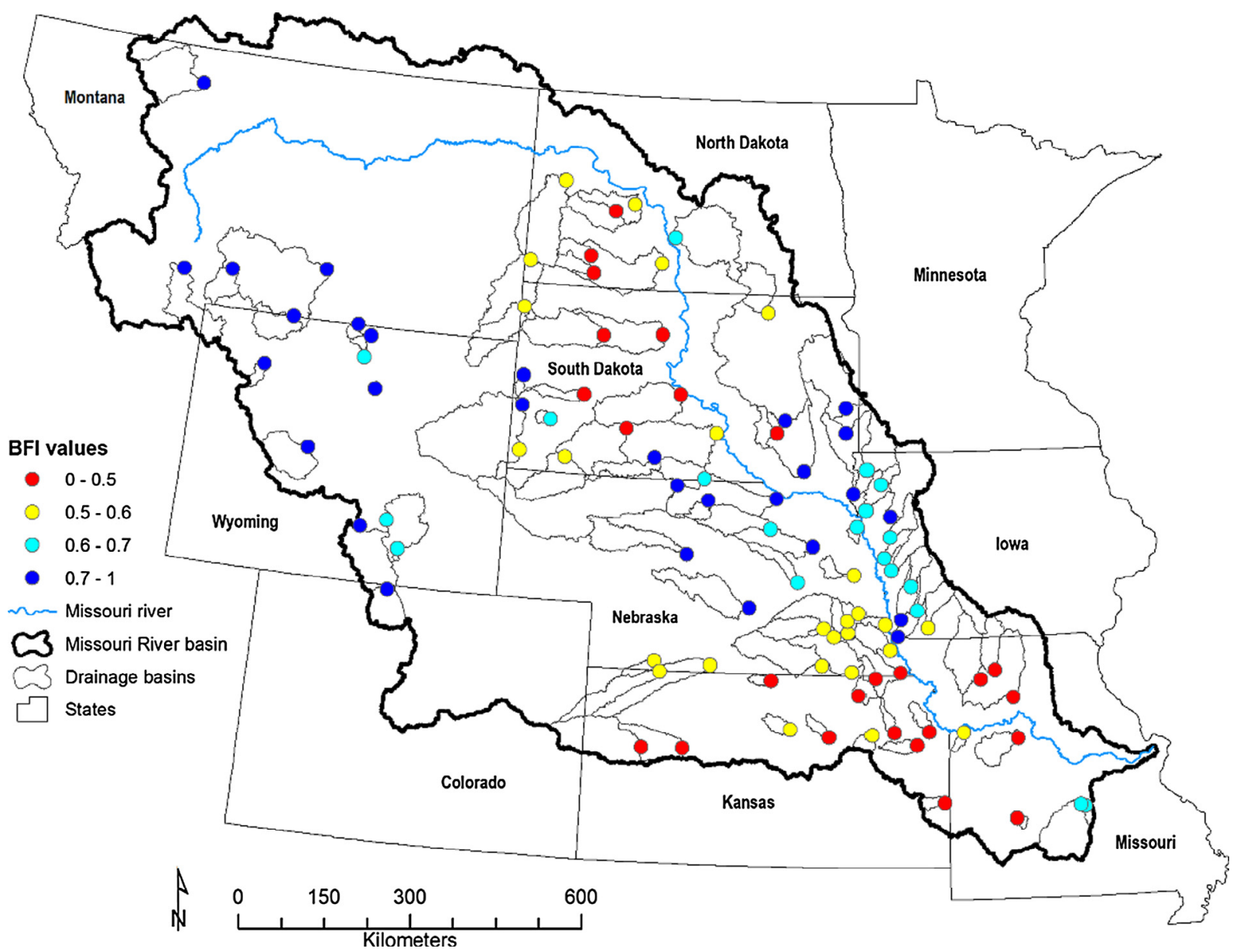

Fig. 4. Baseflow index (baseflow/streamflow) for the Missouri River Basin.

forest, grassland, and shrubland in the Ozark Plateaus, contribute more surface runoff than baseflow to streamflow (Fig. 4). Although this complements previous research which associates high elevation to increased baseflow (Rumsey et al., 2015), higher BFI values in the Plains (i.e. central MORB; Fig. 4), where the terrain is relatively low comparable to west of the basin, may be due to the influence of concurrent factors, such as land use, soil composition, and elevation (Price, 2011). Soil permeability, underlying aquifers, and hydrologic landscape regions play a major role in baseflow distribution in the basin (Eckhardt, 2005, 2008; Santhi et al., 2008); however, more detailed analysis, which is beyond the scope of this study, is needed to examine the influence of these factors on baseflow before drawing definite conclusions. Overall, baseflow was a large proportion of total streamflow in the MORB during the period examined (Table 2), increasing in the western edge followed by downstream east, then the middle (Figs. 3 and 4).

\subsection{Agricultural land use change}

The dominant land use types in MORB are farmland (i.e. agricultural land) and grassland (Fig. 1), which account for $25 \%$ and $47 \%$, respectively, based on NLCD 2011. The general trend for land use change in MORB during the study period is that increased agricultural land use coincided mostly with decreased grassland (not shown here). Cropland coverage seems to have increased considerably at the beginning of the $70 \mathrm{~s}$ mainly in Iowa and Montana (Fig. 5). This increase of cropland coverage is likely due to data irregularities and reporting issues. For Ida County in Iowa, for example, soybeans and oats started to be reported only in 1973 , leading to rapid increase in agricultural land coverage (Fig. 5). The answer to the source of this uncertainty requires a detailed analysis of the CDLs. Overall, increase in cropland coverage is not noticeable in most states within MORB from $70 \mathrm{~s}$; however, the total cropland coverage in the basin decreased before $70 \mathrm{~s}$ but increased by 30\% between 1970 and 2014 (Fig. 5).

\subsection{Trends in baseflow and precipitation}

A summary of the trend analysis results is shown in Table 3 and Figs. 6 and 7. The analysis indicated that 33 (33\%) stations have significant trends with 28 out of 33 (85\%) positive slopes for the total annual precipitation. Stream gauge stations 06894000 and 06908000 located in Missouri showed the greatest significant positive upward trend ( $50.4 \mathrm{~mm} / 10$-year) and stream gauge station 06207500 located in Montana indicated the greatest significant downward slope of $-39.8 \mathrm{~mm} / 10$-year.

Baseflow trend analysis showed 73 (74\%) and 26 (26\%) stations with positive and negative slopes, respectively (Table 3 ). Out of the 99 streamflow gauge stations, 47 (47\%) stations indicated significant trends with 40 out of 47 (85\%) upward and 7 out of 47 (15\%) downward slopes. Station 06894000 located in Missouri indicated the greatest significant positive slope $(19.0 \mathrm{~mm} / 10-\mathrm{yr})$ and station 06278300 located in Wyoming demonstrated the greatest significant negative trend $(-14.3 \mathrm{~mm} / 10-\mathrm{yr})$.

A comparison between precipitation and baseflow trends showed that baseflow trends had a higher number of significant positive slopes (40 stations) than precipitation (28 stations) (Table 3). All states except Colorado and Wyoming indicated 


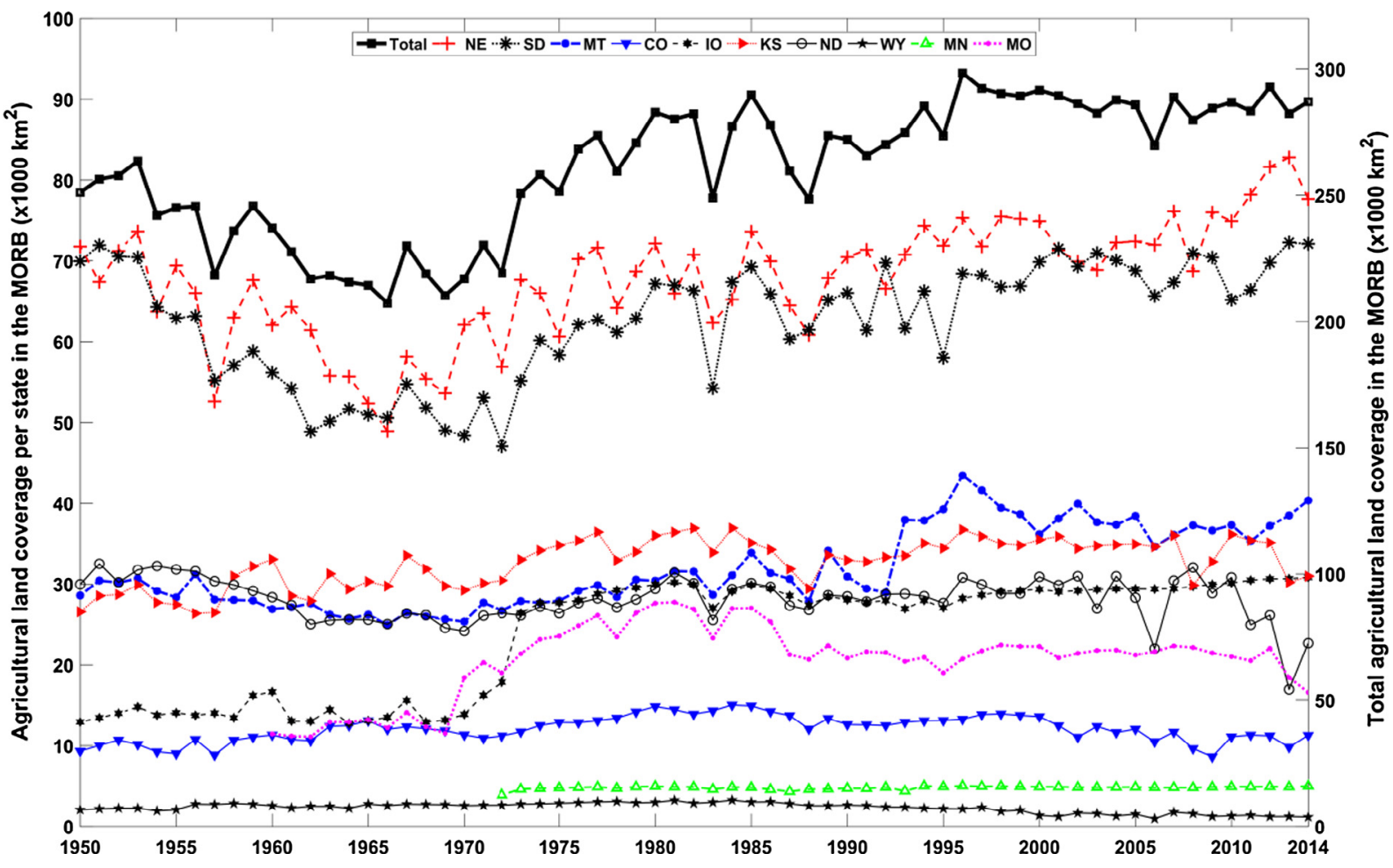

Fig. 5. Estimated agricultural land use change in the Missouri River Basin between 1950 and 2014.

Table 3

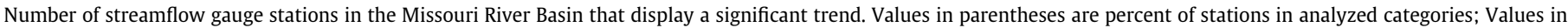
bold show significant trends.

\begin{tabular}{|c|c|c|c|c|c|c|}
\hline & Positive trend & Negative trend & Significant & Significant positive & Max positive slope $(\mathrm{mm} / 10-\mathrm{yr})$ & Max negative slope $(\mathrm{mm} / 10-\mathrm{yr})$ \\
\hline Coverage & \multicolumn{6}{|c|}{ Annual precipitation } \\
\hline MORB & $78(79 \%)$ & $21(21 \%)$ & $33(33 \%)$ & $28(85 \%)$ & 50.4 & -39.8 \\
\hline Colorado & 1 & 0 & 1 & 1 & 15.8 & NA \\
\hline Iowa & 9 & 2 & 6 & 6 & 36.9 & -15.2 \\
\hline Kansas & 9 & 4 & 1 & 1 & 28.7 & -17.3 \\
\hline Missouri & 8 & 0 & 4 & 4 & 50.4 & NA \\
\hline Montana & 3 & 2 & 1 & 0 & 9.2 & -39.8 \\
\hline Nebraska & 18 & 7 & 7 & 6 & 15.0 & -15.3 \\
\hline North Dakota & 5 & 2 & 1 & 1 & 15.7 & -7.0 \\
\hline South Dakota & 18 & 2 & 9 & 8 & 30.1 & -10.0 \\
\hline Wyoming & 7 & 2 & 3 & 1 & 11.6 & -11.1 \\
\hline \multicolumn{7}{|l|}{ Annual baseflow } \\
\hline MORB & $73(74 \%)$ & $26(26 \%)$ & $47(47 \%)$ & $40(85 \%)$ & 19.0 & -14.3 \\
\hline Colorado & 0 & 1 & 0 & 0 & NA & -0.8 \\
\hline Iowa & 11 & 0 & 11 & 11 & 17.0 & NA \\
\hline Kansas & 10 & 3 & 5 & 2 & 9.0 & -0.1 \\
\hline Missouri & 8 & 0 & 5 & 5 & 19.0 & NA \\
\hline Montana & 0 & 5 & 1 & 0 & NA & -6.9 \\
\hline Nebraska & 17 & 8 & 13 & 11 & 14.0 & -1.2 \\
\hline North Dakota & 3 & 4 & 1 & 1 & 0.3 & -0.4 \\
\hline South Dakota & 20 & 0 & 10 & 10 & 9.7 & NA \\
\hline Wyoming & 4 & 5 & 1 & 0 & 3.9 & -14.3 \\
\hline
\end{tabular}

greater significant positive slopes for baseflow. Montana showed none and North Dakota showed one station with significant upward trend for both total annual precipitation and baseflow. The fact that baseflow showed more significant upward trends than precipitation, may be due to addition of snowmelt to precipitation input and the potential impact of greater amount of runoff on the baseflow (Ryberg et al., 2015).

Generally, precipitation and/or baseflow increased in the eastern MORB, especially in Iowa and Missouri, and in some pockets in the west, with greater slopes of trends compared to other parts of the basin (Figs. 6 and 7). Statistically significant trends in base- flow and precipitation were not detected in the majority of the central Great Plains (Figs. 3 and 6). Sixty-eight stations exhibited matching positive (60) or negative (8) trends in precipitation and baseflow, and 31 stations had opposite trends (i.e. upward baseflow trends and downward precipitation trends or vice versa) (Fig. 7). Out of 31 stations with opposite trends, 18 stations had positive precipitation and negative baseflow trends, while the other 13 stations had negative precipitation and positive baseflow trends. Some stations had opposite trends with high alternated slopes. This is the case of station 06808500 in an agricultural area of southwest Iowa with $-15.2 \mathrm{~mm} / 10-\mathrm{yr}$ precipitation trend slope and $17 \mathrm{~mm} / 10-\mathrm{yr}$ 


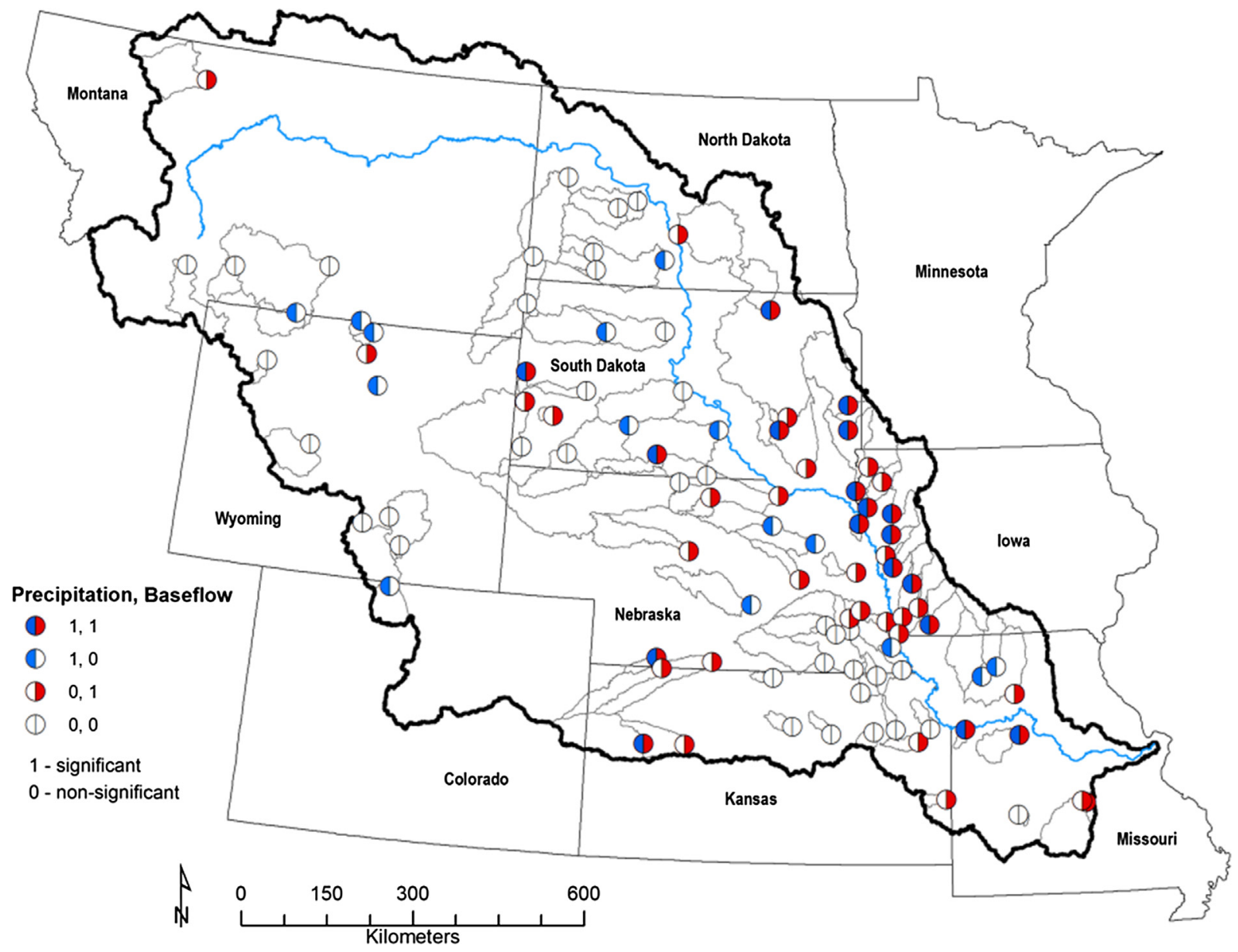

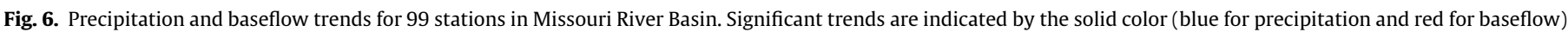
and non-significant trends are shown by white color.

baseflow trend slope. Station 06278300 in a forested area of Wyoming also shows significant opposite trends $(4.4 \mathrm{~mm} / 10$-yr for precipitation and $-14.3 \mathrm{~mm} / 10$-yr for baseflow). In Iowa, this can be explained by intensifications of corn production from the $1970 \mathrm{~s}$ and soybean production from the 1980s (Xu et al., 2013a). Based on 1930s to 2010 streamflow and precipitation data, Xu et al. (2013a) also found a linkage between increased baseflow and land use change in four Midwest states including Iowa.

In a study of the Upper Mississippi River Basin, Kochendorfer and Hubbart (2010) found increasing trend in precipitation for southwest Minnesota, west Iowa, and northeast Missouri, which neighbor Missouri River Basin. Based on data for 1960-2011, Norton et al. (2014) indicated a slightly increasing trend for the mean of the total annual precipitation in the Missouri River Basin. Garbrecht et al. (2004) studied two watersheds in Nebraska and showed an increase in precipitation in both watersheds based on data for 1895-2001. Rahmani et al. (2015) indicated an increasing trend in precipitation for the majority of Kansas using data from 1890 to 2011. Kibria et al. (2016) found an upward trend in precipitation for the majority of stations in South Dakota based on 63 years of data (1951-2013). Other studies also reported increases in precipitation in the Midwest and Central US (up to $4 \%$ per decade) within recent decades (e.g. Pryor et al., 2009; Karl et al., 2009). For the MORB, Norton et al. (2014) found that out of 227 stations, 45 indicated significant increasing trend and 56 showed significant decreasing trend in the annual streamflow. Because baseflow is a major contributor of streamflow (Lim et al., 2005), the streamflow increase in Norton et al. (2014) was likely driven by the increased baseflow. In South Dakota, Kibria et al. (2016) found increasing trends in streamflow and baseflow respectively for $39 \%$ and $50 \%$ of the 18 studied watersheds. Increasing trends have also been observed in the central area of the Upper Mississippi River Basin over 1939-2008 using data for 48 stations (Kochendorfer and Hubbart, 2010).

Even though baseflow exhibits more significant upward trends than precipitation (Fig. 6; Table 3), it appears that upward trends in baseflow generally coincide with increasing precipitation trends in most states of the basin including the Dakotas, Nebraska, Missouri, Kansas, and Iowa, with the largest slopes of precipitation and baseflow trends in eastern MORB (i.e. Iowa and Missouri) (Figs. 6 and 7). The western part of the basin generally shows varying direction in baseflow and precipitation trends (Fig. 7), suggesting that variation in precipitation (i.e. rainfall) may not be very influential in baseflow variation during the study period. Precipitation is greater in eastern MORB and falls mainly in the form of rain in most parts of eastern MORB compared to western MORB where snowfall is a significant component of the precipitation amount (Norton et al., 2014). In the mountain regions of MORB, baseflow may increase with spring snowmelt inputs to the stream channel, especially in high-altitude regions with underlying permafrost (Price, 2011; Brabets and Walvoord, 2009).

\subsection{Precipitation elasticity of baseflow}

The impact of precipitation on baseflow was evaluated using the climate elasticity coefficient in Eq. (10) (Fig. 8). Baseflow 


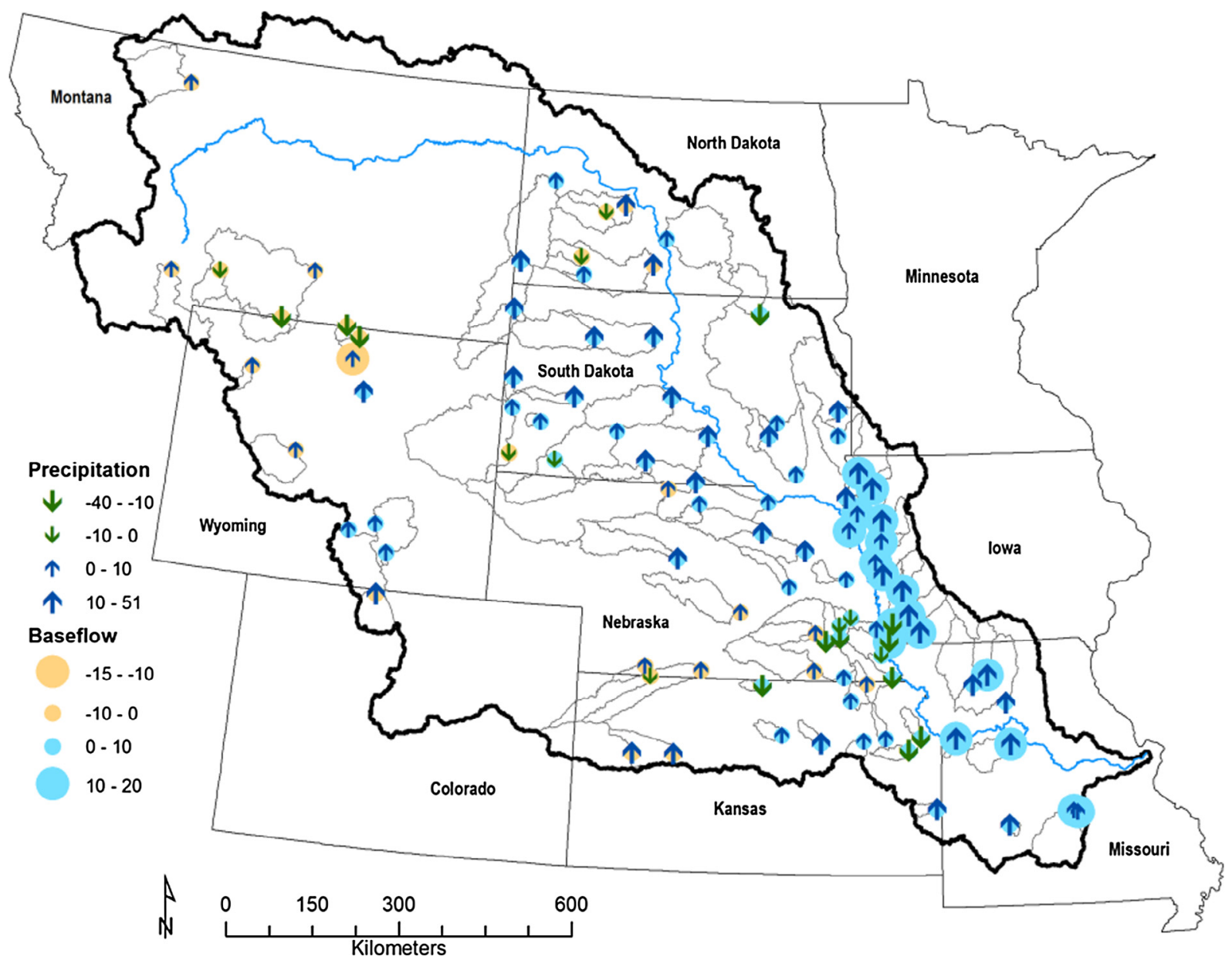

Fig. 7. Slopes of precipitation and baseflow trends in the Missouri River Basin.

positively correlated to changes in precipitation in 97 gauge stations in MORB while two stations (06847500 and 06853800) showed the opposite response in baseflow with increased precipitation in 0684750 and decreased precipitation in 06853800. Twenty-seven stations showed significant impact of $1 \%$ precipitation change on baseflow (from 2\% to 3.9\%; dark blue in Fig. 8), while the impact in 70 stations was moderate ranging from 0 to $2 \%$ (light blue and yellow in Fig. 8). The decrease in baseflow with increased precipitation was found small with a maximum of $0.18 \%$ in only two stations. Of all 99 stations, the average $e_{P}$ was 1.51 with standard deviation of 0.84 .

In 13 stations located in the mountain and forested area of the Northern Rockies region in Wyoming and Montana, the elasticity coefficient was positive and did not exceed a unity (Fig. 8), which indicates a proportional impact of precipitation on baseflow. In the Great Plains region of North Dakota, South Dakota, and eastern parts of Iowa and Missouri, the impact of precipitation on baseflow is very strong with elasticity coefficient reaching 3.9 (Fig. 8). According to Fig. 3, the baseflow yield and values of BFI are also higher there, showing a significant contribution of baseflow to streamflow in that region. These findings align well with previous studies, which also found that climate was the major impacting factor for streamflow increase in Iowa, South Dakota, and Minnesota (e.g. Ryberg et al., 2014; Kibria et al., 2016; Novotny and Heinz, 2006). Overall, baseflow in western part of the basin appears to be less sensitive to increased precipitation than baseflow in the eastern MORB (Fig. 8). In other words, while baseflow generally increased with increased precipitation over the basin during the study period, the influence of precipitation on baseflow is more noticeable in the eastern MORB (Fig. 8). This is also reflected in baseflow and trend analyses (Fig. 7) and is likely due to the fact that western states receive less incident precipitation amount compared to eastern states. Consequently, total annual precipitation is greater in eastern MORB, which may result in a stronger influence on baseflow. In addition, the influence of precipitation on baseflow was likely augmented by the potential impact of snowmelt on runoff in the basin during the study period; snowmelt was not explicitly examined in the present study.

\subsection{Agricultural land use change elasticity of baseflow}

The impact of land use on annual baseflow varied from one gauge station to another. Annual baseflow increased with increased agricultural land use change in 52 of the 99 gauge stations (Table 3; Fig. 9). Of these stations, there was a visible influence of land use on baseflow in only 11 stations in which a $1 \%$ increase in cropland coverage resulted in $1 \%$ to $4 \%$ increase in annual baseflow. Of the stations with negative correlation between agricultural land use and annual baseflow, 20 resulted in discernible influence in which a slight increase in land use or rainfall would result in a great decrease in baseflow. Within this category, a $1 \%$ increase in land use resulted in $1 \%$ to $5.7 \%$ decrease in annual baseflow $\left(e_{\mathrm{AgLU}}<-1\right.$ in Fig. 9). The influence of cropland coverage on baseflow in the basin showed varying results. This is expected as agricultural land use change fluctuated during the study period (see Fig. 5). Overall, a $1 \%$ increase within the MORB 


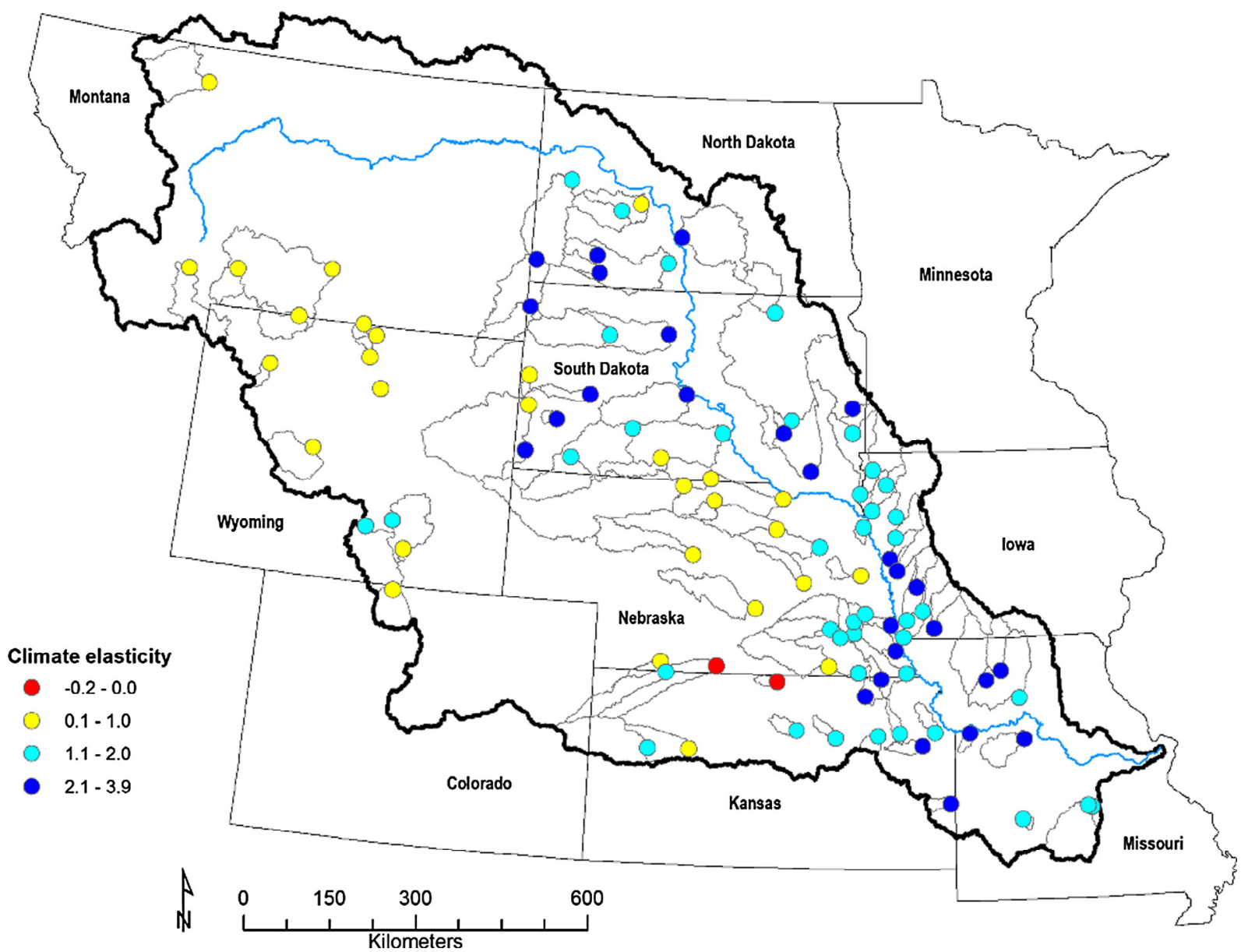

Fig. 8. Precipitation elasticity of baseflow at 99 undisturbed watersheds in the Missouri River Basin.

agricultural land use would result in a $0.2 \%$ decrease in baseflow on average. While baseflow was sensitive to agricultural land use change across MORB during the study period, baseflow increased more with increased precipitation in the basin with four stations that show very high agricultural land use change elasticity of baseflow $\left(e_{\mathrm{AgLU}}>2\right.$; Fig. 9 ). With high positive elasticity coefficients for both precipitation and agricultural land use in east and pockets in west of MORB (Figs. 8 and 9), intensification of climate and land use change (i.e. increase in precipitation and land use change) appears to increase baseflow in these parts of the basin. In other parts of the basin, baseflow appears to decrease with increase in cropland coverage during the study period (Fig. 9). These mixed results can be attributed to variability in climate, soil composition, land use and associated activities across the basin.

Results obtained in this study are in agreement with the findings from Price (2011) who reported based on an extensive literature review that the response of baseflow to agricultural land may be either positive or negative, depending on management practices. For example, presence of crop irrigation affected baseflow differently depending on the source of water. If surface water resources connected to the stream network serves as the source of irrigation water, increased ET might reduce baseflow. Conversely, irrigation water is drawn from disconnected storage resources or from outside the study area may increase baseflow. Although approximately 12 million acres ( 4.86 million ha) of the cropland in the MORB is irrigated (http://missouri.crces.org/), there was no differentiation between irrigated and rain fed cropland for each of the sites in this study. For simplicity and based on the objective of the study, land use was categorized as cropland and non-cropland; land management and agricultural conservation practices were not explicitly evaluated in this study. For instance, varied management practices are associated with a wide range of soil impacts (e.g. conventional tillage practices versus notill and conservation tillage), differing temporal patterns to cropping (seasonal or perennial cropping systems), and whether or not soil cover is used during the fallow season (Price, 2011) as well drainage water management (Schilling and Libra, 2003; Schilling and Helmers, 2008). For instance, converting perennial vegetation to seasonal row crops may lead to reduced evapotranspiration, increased groundwater recharge, and increased baseflow (Zhang and Schilling, 2006). Therefore, we recommend that further studies be carried out especially for the two categories where land use increase caused a great increase (or decrease in baseflow (Table 3and Fig. 9, dark blue and deep red) as well as for land management practices.

\subsection{Comparison of precipitation and agricultural land use change elasticities of baseflow}

The scatterplot in Fig. 10 shows the variability in precipitation and agricultural land use elasticity coefficients in 99 undisturbed drainage basins within MORB. In general, the chart exhibits higher positive impact of precipitation with less variability (Median $=1.54$ and St. Dev. $=0.84)$ on the baseflow than the impact by agricultural land use (Median $=0.01$ and St. Dev. = 1.66). Both coefficients display a weak inter-correlation but are mostly within a range of low values. Catchments in three western states (Colorado, Montana, 


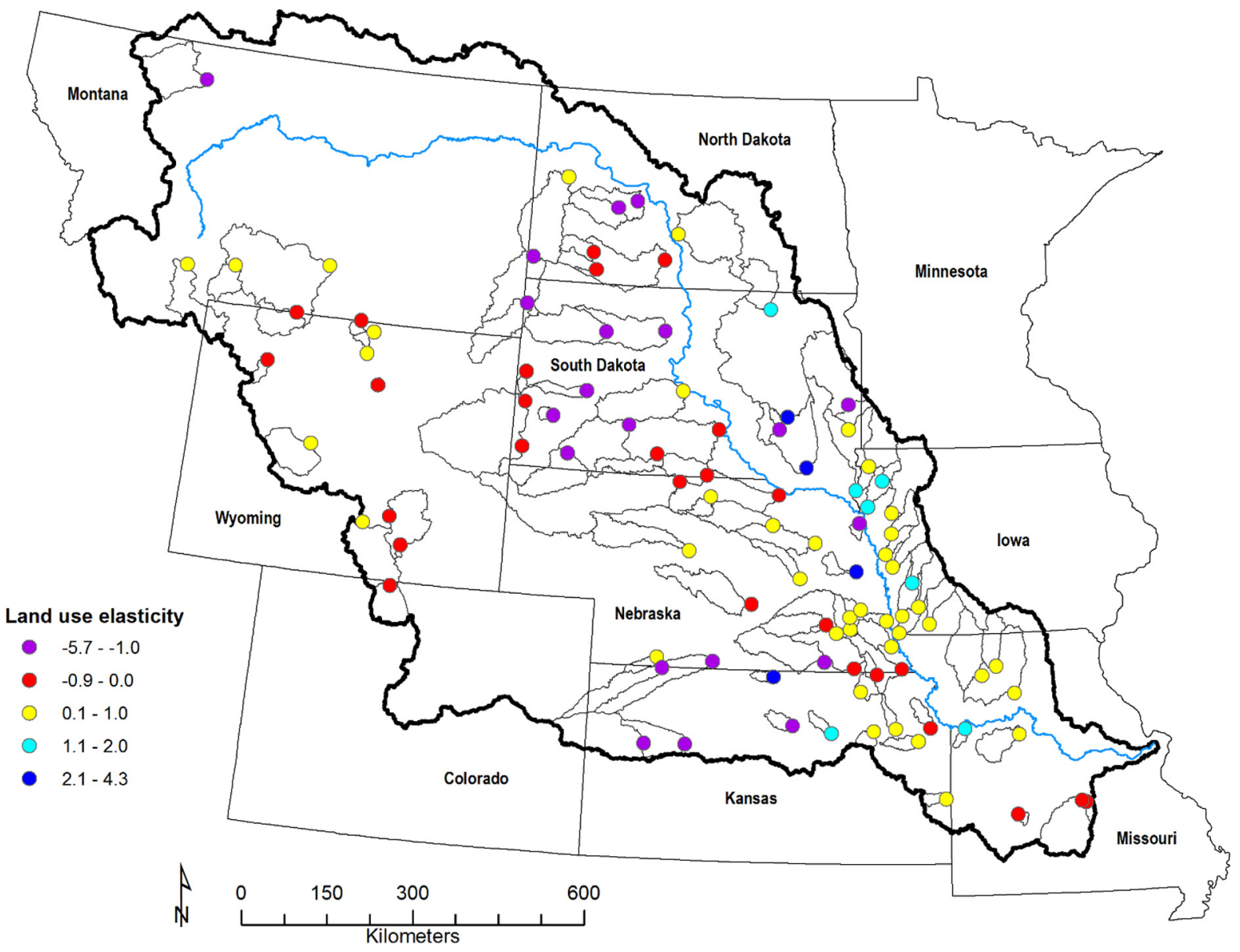

Fig. 9. Agricultural land use elasticity of baseflow at 99 undisturbed watersheds in the Missouri River Basin.

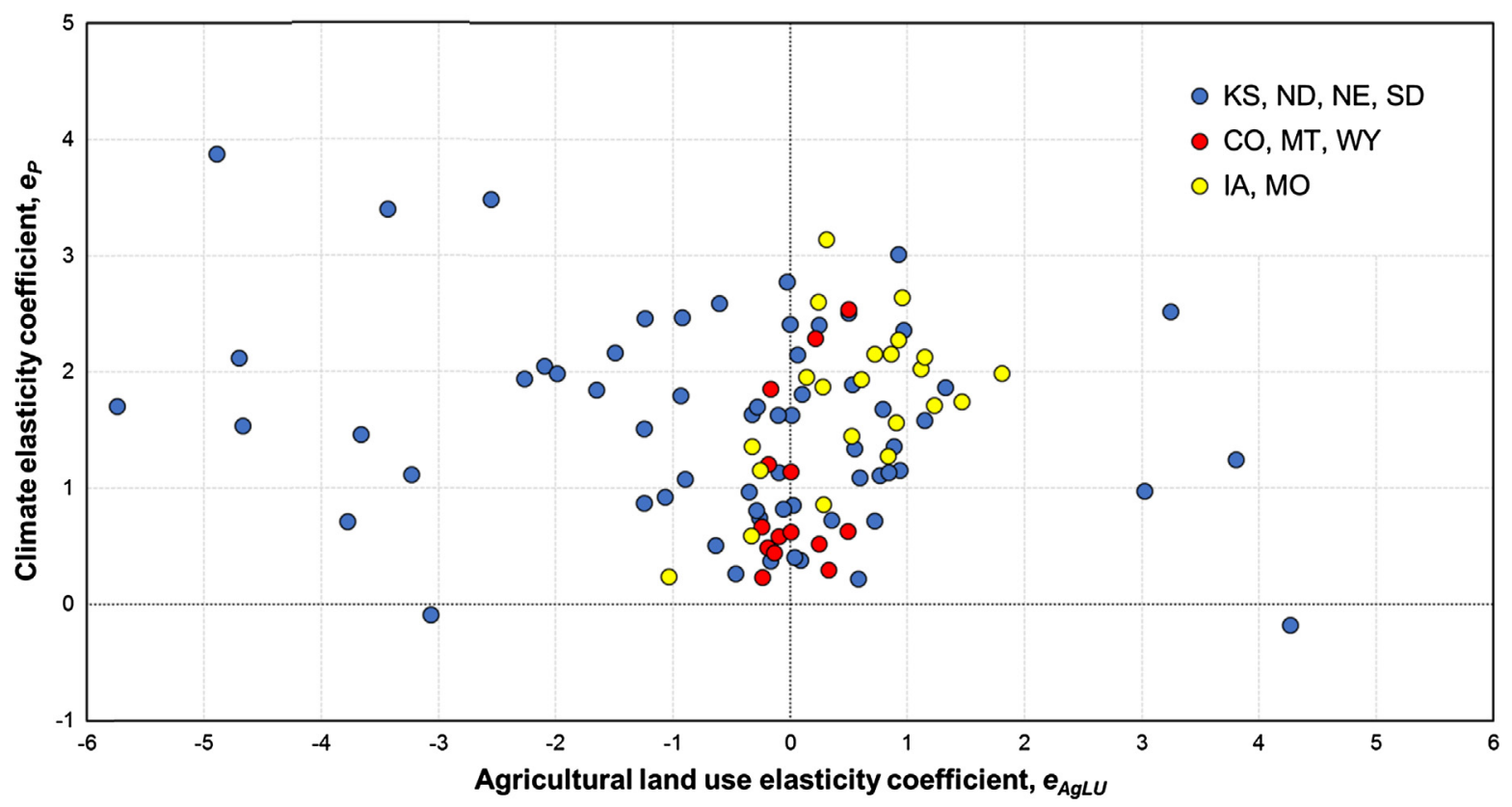

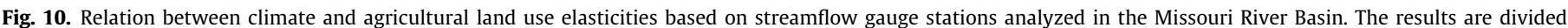

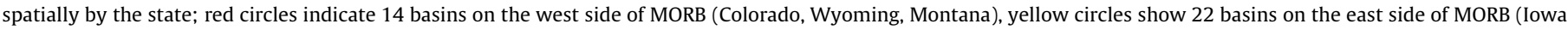
and Missouri), and blue circles represent 63 basins in the Central Great Plains states (North Dakota, South Dakota, Nebraska, Kansas).

and Wyoming) showed very little influence of agricultural land use on baseflow (Median $=-0.05$ and St. Dev. $=0.27$ ), mainly due to agricultural production that occupied less than $5 \%$ of the area. In
Iowa, east Nebraska, north east Kansas, and Missouri, baseflow showed upward trend with increased agricultural land coverage (Fig. 9). Additionally, precipitation and baseflow had also upward 
and mostly significant trends over past several decades in two eastern states of Iowa and Missouri (Figs. 6 and 7). These trends resulted in comparable positive impacts of climate and agricultural land use on baseflow with St. Dev. of 0.67 for both elasticity coefficients.

The highest variation in elasticity coefficients was found to be for the watersheds within the Central Great Plains region of MORB. The positive values of $e_{\mathrm{AgLU}}$ were found in the watersheds close to Iowa while negative values clustered closer to the west side of central states (see Fig. 9). Changes in baseflow patterns can be attributed to concurrent changes in agricultural land use and precipitation, especially in eastern MORB, where Xu et al. (2013a) reported stronger influence of land use change than climate on baseflow with corn and soybean production systems in the 1970s and 1980s for Iowa. Agricultural production in 63 undisturbed watersheds in four central states is significant (average over $31 \%$ ) but the larger range of variability for agricultural land use coefficient suggests that the influence of agricultural production on baseflow vary widely, from low to high, compared to the effect of precipitation on baseflow. This may be due to the fact that upland agricultural activities foster many management practices which exert varying influence on downstream waters. Findings from the present study are consistent with previous studies. While some studies reported stronger climate impact on streamflow than land use in North-Central US including South Dakota and Minnesota (e.g. Ryberg et al., 2014; Kibria et al., 2016; Novotny and Heinz, 2006), other researchers indicated that land use change and land management practices was the main driver for streamflow and baseflow increases in the Upper Mississippi River Basin including Iowa (e.g. Schilling et al., 2008; Schilling and Libra, 2003; Xu et al., 2013a). Selection of the study periods that drive the core datasets for land use and climate impact studies can also affect the conclusions of the study. For example, Xu et al. (2013a) reported that land use change exerted a stronger influence on baseflow than climatic effect between 1930s and 2010 in Ohio, Indiana, Illinois, and Iowa. For the same Midwest region, a similar analysis with 1950 s to 2000 data showed that increasing trends in streamflow and baseflow were driven more by climate than human activity (Xu et al., 2013b).

\section{Conclusions}

Long-term baseflow records (1950-2014) for 99 streamflow gauge stations were analyzed for yield, trend, and elasticity to precipitation and agricultural land use change in the MORB. Results revealed that baseflow accounts for $60 \%$ of streamflow in the basin. Baseflow yield generally increase in the far west and east of the basin (i.e. upstream and downstream). Baseflow variations were influenced by the dynamic interactions of precipitation and agricultural land use change with varying patterns and degrees across the basin. During the study period, baseflow and precipitation showed upward trends at majority of the gauge stations in the basin. This supports the positive correlation between annual baseflow and annual precipitation at nearly all gauge stations with positive trends but more noticeable in east and pockets in west MORB. Based on the analysis, baseflow appears to increase also with increased cropland coverage mainly in eastern MORB (18 watersheds in Iowa and Missouri; 0.1-4\%), and decreased with increased agricultural land use in the remaining basin (0-5.7\%). A $1 \%$ increase in precipitation augments baseflow by $0.1-3.9 \%$ for 97 of 99 stations. On average, a $1 \%$ increase in precipitation results in $1.5 \%$ increase baseflow, while a $1 \%$ increase in agricultural land use leads to a $0.2 \%$ decrease in baseflow within the basin, suggesting that agricultural land use change exerts a weaker influence on baseflow compared to precipitation.
While the results of statistical analysis may not capture all underlying mechanics of landform complexity in the basin (e.g. mountains and plains), this study provides useful insight on the distribution of baseflow, as well as on climate and land use controls on baseflow and streamflow in the MORB. Such information can be used for effective future planning and management of water resources in the region. While the impact of agricultural land use on baseflow during the study period is less uniform than that of precipitation over the basin, recent trends in agricultural land use change in the region may eventually shift this impact, calling for more research. This study focuses on agricultural land use change in the MORB, which has a predominance of pasture/grassland also. An analysis of baseflow sensitivity to grassland change and land management practices should be beneficial for decision making in water resources. The results obtained in this study are dependent on accuracy of the crop data layer product and algorithm used for baseflow separation, and could result in varying outcomes with changes in datasets and methods.

\section{Acknowledgments}

Thanks to Alan Verser at the USDA-ARS Grazinglands Research Laboratory, El Reno, Oklahoma for his invaluable assistance with processing the land use data. Thanks also to ABE graduate students at South Dakota State University who helped with data processing and compilation. This study was partially supported by the USDANIFA; Project No. SD00H542-15, and the Kansas Agricultural Experiment Station, Manhattan, Kan., Contribution No. 16-327-J. Thanks to the two anonymous reviewers for their constructive comments that greatly improved the initial manuscript.

\section{Appendix A. Supplementary data}

Supplementary data associated with this article can be found, in the online version, at http://dx.doi.org/10.1016/j.jhydrol.2017.05. 055. These data include Google maps of the most important areas described in this article.

\section{References}

Ahiablame, L., Chaubey, I., Engel, B., Cherkauer, K., Merwade, V., 2013. Estimation of annual baseflow at ungauged sites in Indiana USA. J. Hydrol. 476, 13-27.

Brabets, T.P., Walvoord, M.A., 2009. Trends in streamflow in the Yukon River Basin from 1944 to 2005 and the influence of the Pacific Decadal Oscillation. J. Hydrol. $371,108-119$.

Brikowski, T.H., 2008. Doomed reservoirs in Kansas, USA? Climate change and groundwater mining on the Great Plains lead to unsustainable surface water storage. J. Hydrol. 354, 90-101.

Bruijnzeel, L., 2004. Hydrological functions of tropical forests: not seeing the soil for the trees? Agric. Ecosyst. Environ. 104, 185-228.

Burch, D., Coffin, M., Siefert-Spilde, R., Moehring, R., Slade Franklin, S., 2007. Missouri River Watershed Coalition Saltcedar Management Plan Available at: http://www.weedcenter.org/mrwc/docs/about-us-saltcedar-plan.pdf. Accessed July 15, 2015.

Chiew, F.H., Peel, M.C., McMahon, T.A., Siriwardena, L.W., 2006. Precipitation elasticity of streamflow in catchments across the world. IAHS Publ. 308, 256.

Choi, W., 2008. Catchment-scale hydrological response to climate-land-use combined scenarios: a case study for the Kishwaukee River basin, Illinois. Phys. Geogr. 29 (1), 79-99.

Devito, K., Creed, I., Gan, T., Mendoza, C., Petrone, R., Silins, U., Smerdon, B., 2005. A framework for broad-scale classification of hydrologic response units on the Boreal Plain: is topography the last thing to consider? Hydrol. Processes 19 (8), 1705-1714.

Dixon, H., Lawler, D.M., Shamseldin, A.Y., 2006. Streamflow trends in western Britain. Geophys. Res. Lett. 33, L19406.

Dudley, R.W., Hodgkins, G.A., 2013. Historical groundwater trends in northern New England and relations with streamflow and climatic variables. J. Am. Water Res. Assoc. 49 (5), 1198-1212.

Eckhardt, K., 2005. How to construct recursive digital filters for baseflow separation. Hydrol. Proc. 19 (2), 507-515.

Eckhardt, K., 2008. A comparison of baseflow indices, which were calculated with seven different baseflow separation methods. J. Hydrol. 352, 168-173. 
Fenneman, N.M., and Johnson, D.W., 1946, Physiographical divisions of the conterminous United States: U.S. Geological Survey special map, scale 1:7,000,000, accessed February 4, 2014, at http://water.usgs.gov/GIS/metadata/ usgswrd/XML/physio.xml.

Ficklin, D.L., Robeson, S.M., Knouft, J.H., 2016. Impacts of recent climate change on trends in baseflow and stormflow in United States watersheds. Geophys. Res. Lett. 43 (10), 5079-5088.

Fu, G., Chiew, F., Charles, S., \& Mpelasoka, F. (2011). Assessing precipitation elasticity of streamflow based on the strength of the precipitation-streamflow relationship. In Proceedings of the 19th International Congress on Modelling and Simulation (pp. 3567-3572).

Garbrecht, J., Van Liew, M., Brown, G.O., 2004. Trends in precipitation, streamflow, and evapotranspiration in the Great Plains of the United States. J. Hydrol. Eng. 9 (5), 360-367.

Hall, K.T., Crovetti, J.A. 2007. Effects of Subsurface Drainage on Pavement Performance. National Cooperative Highway Research Program. Transportation Research Board. NCHRP REPORT 583. Available at http:// onlinepubs.trb.org/onlinepubs/nchrp/nchrp_rpt_583.pdf. accessed on May 24 2016

Hamed, K.H., Rao, A.R., 1998. A modified Mann-Kendall trend test for autocorrelated data. J. Hydrol. 204, 182-196.

Hirsch, R.M., Slack, J.R., Smith, R.A., 1982. Techniques of trend analysis for monthly water quality data. Water Resour. Res. 18, 107-121.

Homer, C.G., Dewitz, J.A., Yang, L., Jin, S., Danielson, P., Xian, G., Coulston, J., Herold, N.D., Wickham, J.D., Megown, K., 2015. Completion of the 2011 national land cover database for the conterminous United States-representing a decade of land cover change information. Photogramm. Eng. Remote Sens. 81 (5), 345 354.

Huntington, T.G., Richardson, A.D., McGuire, K.J., Hayoe, K., 2009. Climate and hydrologic changes in the northeastern United States: recent trends and implications for forested and aquatic ecosystems. Can. J. For. Res. 39 (2), 199212.

IPCC (Intergovernmental Panel on Climate Change), (2014). Climate Change 2014 Impacts, Adaptation, and Vulnerability. Part A: Global and Sectoral Aspects. Contribution of Working Group II to the Fifth Assessment Report of the Intergovernmental Panel on Climate Change [Field, C.B., V.R. Barros, D.J. Dokken, K.J. Mach, M.D. Mastrandrea, T.E. Bilir, M. Chatterjee, K.L. Ebi, Y.O. Estrada, R.C. Genova, B. Girma, E.S. Kissel, A.N. Levy, S. MacCracken, P.R. Mastrandrea, and L. L. White (eds.)]. Cambridge University Press, Cambridge, United Kingdom and New York, NY, USA, 1132 pp.

IPCC (Intergovernmental Panel on Climate Change), (2014). Climate Change 2014: Impacts, Adaptation, and Vulnerability. Part B: Regional Aspects. Contribution of Working Group II to the Fifth Assessment Report of the Intergovernmental Panel on Climate Change [Barros, V.R., C.B. Field, D.J. Dokken, M.D. Mastrandrea, K.J. Mach, T.E. Bilir, M. Chatterjee, K.L. Ebi, Y.O. Estrada, R.C. Genova, B. Girma, E. S. Kissel, A.N. Levy, S. MacCracken, P.R. Mastrandrea, and L.L. White (eds.)]. Cambridge University Press, Cambridge, United Kingdom and New York, NY, USA, $688 \mathrm{pp}$

Juckem, P.F., Hunt, R.J., Anderson, M.P., Robertson, D.M., 2008. Effects of climate and land management change on streamflow in the driftless area of Wisconsin. J. Hydrol. 355 (1-4), 123-130.

Kammerer, J.C., (1987), Largest rivers in the United States: U.S. Geological Survey Open-File Report 87-242. Available at http://pubs.usgs.gov/of/1987/ofr87-242/ Accessed January 24, 2017.

Karl, T.R. et al. (Eds.), 2009. Global Climate Change Impacts in the United States. Cambridge University Press.

Kendall, M.G., 1975. Rank Correlation Methods. Griffin, London.

Kibria, K.N., Ahiablame, L., Hay, C., Djira, G., 2016. Streamflow trends and responses to climate variability and land cover change in South Dakota. Hydrology 3 (1), 2. http://www.mdpi.com/2306-5338/3/1/2/htm.

Kochendorfer, J.P., Hubbart, J.A., 2010. The roles of precipitation increases and rura land-use changes in streamflow trends in the Upper Mississippi River Basin. Earth Inter. 14 (20), 1-12.

Kumar, S., Merwade, V., Kam, J., Thurner, K., 2009. Streamflow trends in Indiana: effects of long-term persistence, precipitation and subsurface drains. J. Hydrol. $374,171-183$.

Lim, K.J., Engel, B.A., Tang, Z., Choi, J., Kim, K., Muthukrishnan, S., Tripathy, D., 2005 Automated web GIS-based hydrograph analysis tool. WHAT. J. Am. Water Resour. Assoc. 41 (6), 1407-1416.

Lins, H.F., Slack, J.R., 1999. Streamflow trends in United States. Geophys. Res. Lett. 26, 227-230.

Lins, H.F., Slack, J.R., 2005. Seasonal and regional characteristics of US streamflow trends in the United States from 1940 to 1999. Phys. Geogr. 26 (6), 489-501.

Lyne, V.D. and M. Hollick, 1979. Stochastic Time-Variable Rainfall-Runoff Modeling In: Hydro. and Water Resour. Symp. Institution of Engineers Australia, Perth, Australia, pp. 89-92.

Ma, X., Xu, J., Luo, Y., Aggarwal, S.P., Li, J., 2009. Responses of hydrological processes to land-cover and climate changes in Kejie watershed, south-west China. Hydrol. Process. 23, 1179-1191.

Mann, H.B., 1945. Nonparametric tests against trend. Econom. J. Econom. Soc. 13 245-259.

Mehta, V.M., Knutson, C.L., Rosenberg, N.J., Olsen, J.R., Wall, N.A., Bernadt, T.K. Hayes, M.J., 2013. Decadal climate information needs of stakeholders for decision support in water and agriculture production sectors: a Case study in the Missouri River basin. Wea. Climate Soc. 5, 27-42.
Mehta, V.M., Mendoza, K., Daggupati, P., Srinivasan, R., Rosenberg, N.J., Deb, D., 2016. High-resolution simulations of decadal climate variability impacts on water yield in the Missouri River basin with the Soil and Water Assessment Tool (SWAT). J. Hydrometeorol. 17, 2455-2476.

NOAA (National Oceanic and Atmospheric Administration). (2016). Global Climate Change Indicators. NOAA-National Centers for Environmental Information. accessed on May 10, 2016. Available at: http://www.ncdc.noaa.gov/indicators/. accessed on May 10, 2016

NOAA-RCC (National Oceanic and Atmospheric Administration Regional Climate Centers), 2015. Available at http://scacis.rcc-acis.org/. Accessed November 15, 2015.

Norton, P. A., Anderson, M. T., Stamm, J. F., 2014. Trends in annual, seasonal and monthly streamflow characteristics at 227 streamgages in the Missouri River watershed, water years 1960-2011. Scientific Investigation Report 2014-5053. U. S. Department of the Interior. U. S. Geological Survey, Reston, Virginia.

Novotny, E.V., Heinz, G.S., 2006. Stream flow in Minnesota: indicator of climate change. J. Hydrol. 334 (3), 319-333.

Nyenje, P.M., Batelaan, O., 2009. Estimating the effects of climate change on groundwater recharge and baseflow in the upper Ssezibwa catchment, Uganda. Hydrol. Sci. J. 54 (4), 713-726.

Poff, N.L., 1996. Stream hydrological and ecological responses to climate change assessed with an artificial neural network. Limnol. Oceanogr. 41 (3), 857-863.

Price, K., 2011. Effects of watershed topography, soils, land use, and climate on baseflow hydrology in humid regions: a review. Prog. Phys. Geogr. 35 (4), 465492.

Pryor, S.C., Howe, J.A., Kunkel, K.E., 2009. How spatially coherent and statistically robust are temporal changes in extreme precipitation in the contiguous USA? Int. J. Climatol. 29 (1), 31-45.

Rahmani, V., Hutchinson, S. L., Harrington Jr, J. A., Hutchinson, J. M., \& Anandhi, A (2015). Analysis of Temporal and Spatial Distribution and Change-points for Annual Precipitation in Kansas, USA, International Journal of Climatology, Published online in Wiley Online Library (wileyonlinelibrary.com), DOI: 10.1002 /joc.4252.

Rumsey, C.A., Miller, M.P., Susong, D.D., Tillman, F.D., Anning, D.W., 2015. Regional scale estimates of baseflow and factors influencing baseflow in the Upper Colorado River Basin. J. Hydrol. 4, 91-107.

Ryberg, K.R., Lin, W., Vecchia, A.V., 2014. Impact of climate variability on runoff in the North Central United States. J. Hydrol. Eng. 19 (1), 148-158.

Ryberg, K.R., Akyuz, F.A., Wiche, G.J., Lin, W., 2015. Changes in seasonality and timing of peak streamflow in snow and semi-arid climates of the north-central United States, 1910-2012. Hydrol. Process. 30, 1208-1218.

Sankarasubramaniam, A., Vogel, R.M., Limburner, J.F., 2001. Climate elasticity of streamflow in the United States. Water Resour. Res. 37, 1771-1781.

Santhi, C., Allen, P.M., Muttiah, R.S., Arnold, J.G., Tuppad, P., 2008. Regional estimation of baseflow for the conterminous United States by hydrologic landscape regions. J. Hydrol. 351, 139-153.

Schaake, J. C. (1990). From climate to flow, in Climate Change and U.S. Water Resources, edited by P.E. Waggoner, chap. 8, pp. 177-206, John Wiley, New York.

Schilling, K.E., Helmers, M., 2008. Effects of subsurface drainage tiles on streamflow in Iowa agricultural watersheds: exploratory hydrograph analysis. Hydrol. Process. 22 (23), 4497-4506.

Schilling, K.E., Libra, R.D., 2003. Increased baseflow in Iowa over the second half of the 20th century. J. Am. Water Res. Assoc. 39 (4), 851-860.

Schilling, K.E., Jha, M.K., Zhang, Y.-K., Gassman, P.W., Wolter, C.F., 2008. Impact of land use and land cover change on the water balance of a large agricultural watershed: historical effects and future directions. Water Resour. Res. 44, 112.

Sen, P.K., 1968. Estimates of the regression coefficients based on Kendall's tau. J. Am. Stat. Assoc. 63, 1379-1389.

Shu, Yunqiao; Villholth, Karen G. 2012. Analysis of flow and baseflow trends in the Usangu Catchment, Tanzania. Paper presented at the 16th SANCIAHS National Hydrology Symposium, Pretoria, South Africa, 1-3 October 2012. 13p.

Slack, J.R., and Landwehr, J.M., 1992. Hydro-Climatic Data Network: A U.S. Geological Survey streamflow data set for the United States for the study of climate variations, 1874-1988. U.S. Geological Survey Open-File Report 92-129. Available at http://pubs.usgs.gov/of/1992/ofr92-129/. Accessed August 28, 2015

Sloto R.A., Crouse MY (1996) HYSEP: A computer program for streamflow hydrograph separation and analysis. US Geological Survey, Water Resources Investigations Report 96-4040.

Smakhtin, V.Y., 2001. Low flow hydrology: a review. J. Hydrol. 240, 147-186.

Tetzlaff, D., Seibert, J., McGuire, K.J., Laudon, H., Burn, D.A., Dunn, S.M., et al., 2009. How does landscape structure influence catchment transit time across different geomorphic provinces? Hydrol. Process. 23, 945-953.

USDA (U.S. Department of Agriculture), 2013. Summary Report: 2010 National Resources Inventory, Natural Resources Conservation Service, Washington, DC, and Center for Survey Statistics and Methodology, Iowa State University, Ames, Iowa. http://www.nrcs.usda.gov/Internet/FSE_DOCUMENTS/stelprdb1167354 pdf.

USDA-NASS, 2015. NASS Quick stats. Available at: http://www.nass.usda.gov/ Quick_Stats/Accessed October 1, 2015.

USEPA (United States Environmental Protection Agency), 2006, Ecological regions of North America, Level I-II: scale 1:10,000,000, accessed February 3, 2014, at ftp:// ftp.epa.gov/wed/ecoregions/cec na/NA_LEVEL_II.pdf. 
USGS-NWIS, 2015. U.S. Geological Survey National Water Information System database. Available at http://waterdata.usgs.gov/nwis/rt. Accessed August 28, 2015.

Wen, Fujiang, Chen, Xunhong, 2006. Evaluation of the impact of groundwater irrigation on streamflow in Nebraska. J. Hydrol. 327 (3-4), 603-617.

Wilcox, B.P., Taucer, P.I., Munster, C.L., Owens, M.K., Mohanty, B.P., Sorenson, J.R., Bazan, R., 2008a. Subsurface stormflow is important in semiarid karst 672shrublands. Geophys. Res. Lett. 35, L10403.

Wilcox, B.P., Yun, H., Walker, J.W., 2008b. Long-term trends in streamflow from semiarid rangelands: Uncovering drivers of change. Global Change Biol. 14, 6771676-6771689.

Wine, L., Zou, C.B., 2012. Long-term streamflow relations with riparian gallery forest expansion into tallgrass prairie in the Southern Great Plains, USA. For. Ecol. Manage. 266, 170-179.

Wyoming State Wildlife Action Plan (2010). Northeastern Missouri River Basin. Wyoming Game and Fish Department. Available at: https://wgfd.wyo.gov/ web2011/Departments/Wildlife/pdfs/SWAP_NEMISSOURIRIVERBASIN0001608. pdf. Accessed July 15, 2015.

Xie, H., Eheart, J.W., An, H., 2010. Hydrologic and economic implications of climate change for typical river basins of the agricultural Midwestern United States. J. Water Res. Plann. Manage. 134 (3), 205-213.

Xu, X., Scanlon, B.R., Schilling, K., Sun, A., 2013a. Relative importance of climate and land surface changes on hydrologic changes in the US Midwest since the 1930s: implications for biofuel production. J. Hydrol. 497, 110-120.

Xu, X., Liu, W., Rafique, R., Wang, K., 2013b. Revisiting continental U.S. hydrologic change in the latter half of the 20th century. Water Resour. Manage 27, 43374348 .
Yao, C.S., Zhu, H.J., Lu, X., Liu, Y.B., 2009. Study on the impact of socio-economic driving factors of land use change on the ecosystem service values in Fujian Province. J. Nat. Res. 24 (2), 225-233.

Yue, S., Pilon, P., Phinney, B., Cavadias, G., 2002. The influence of autocorrelation on the ability to detect trend in hydrological series. Hydrol. Process. 16 (9), 18071829.

Yusoff, I., Hiscock, K.M., Conway, D. (2002). Simulation of the impacts of climate change on groundwater resources in eastern England. In: Proceedings of Geoscience 2000: Conference on Sustainable Groundwater Development. London: Geological Society of London.

Zhang, Y.K., Schilling, K.E., 2006. Increasing streamflow and baseflow in Mississipp River since the 1940s: Effect of land use change. J. Hydrol. 324 (1), 412-422.

Zhang, X., Izaurralde, R.C., Manowitz, D.H., Sahajpal, R., West, T.O., Thomson, A.M. Xu, M., Zhao, K., LeDuc, S.D., Williams, J.R., 2015a. Regional scale cropland carbon budgets: evaluating a geospatial agricultural modeling system using inventory data. Environ. Model. Software 63, 199-216.

Zhang, A., Zheng, C., Wang, S., Yao, Y., 2015b. Analysis of streamflow variations in the Heihe River Basin, northwest China: trends, abrupt changes, driving factors and ecological influences. J. Hydrol. 3, 106-124.

Zhao, Y., Tu, Z., Jia, J., Yu, X., 2014. Estimating the sensitivity of annual runoff to changes in climate and land use in the Loess Plateau, China. J. Soil Wate Conserv. 69 (3), 221-230.

Zheng, J.K., Yu, X.X., Deng, W.P., Wang, H.N., Wang, Y.S., 2013. Sensitivity of land use changes to streamflow in Chaobai River Basin. J. Hydrol. Eng. 18, 457-464.

Zomlot, Z., Verbeiren, B., Huysmans, M., Batelaan, O., 2015. Spatial distribution of groundwater recharge and base flow: assessment of controlling factors. J Hydrol. 4, 349-368. 